Abd El-Aziz El-Sayed Fouda ${ }^{1^{*}}$, Salah Mahmoud. Rashwan ${ }^{2}$, Howaida. Ibrahim², Reham Ezzat. Ahmed ${ }^{1}$

${ }^{1}$ University El-Mansoura, Department of Chemistry, Faculty of Science, El-Mansoura-35516, Egypt

${ }^{2}$ Suez Canal University, Department of Chemistry, Faculty of Science, Suez, Egypt
Scientific paper ISSN 0351-9465, E-ISSN 2466-2585 UDC:691.73+615.218:620.197.3: 665.7. 038.5 doi: $10.5937 /$ zasmat2003192F

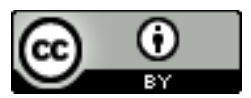

Zastita Materijala 61 (3) 192 - 209 (2020)

\title{
Expired nizatidine drug as eco-friendly corrosion Inhibitor for $\alpha$-brass alloy in aqueous solutions
}

\begin{abstract}
Expired nizatidine drug (END) was studied as inhibitor for $\alpha$-brass in $1 \mathrm{M} \mathrm{HCl}$ utilizing weight loss (WL), and electrochemical methods namely, AC impedance (EIS), Potentiodynamic polarization $(P P)$, and electrochemical frequency modulation (EFM) tests. The protection efficiency (\%IE) was improved with raising in the dose of the expired nizatidine and decreases with raising the temperature. The (\%IE) reaching maximum value $95 \%$ at higher dose of expired nizatidine drug at $25^{\circ} \mathrm{C}$. PP data indicated that nizatidine drug behaves like a mixed kind drug. The protection of $\alpha$-brass corrosion by nizatidine can fit to the adsorption ability of nizatidine drug molecules onto the reactive sites of the $\alpha$-brass surface. The adsorption of the drug follows Langmuir adsorption isotherm. The surface morphology of $\alpha$-brass was investigated. The results obtained from different methods are in excellent agreement.
\end{abstract}

Keywords: Acidic inhibition, $\alpha$-brass, Nizatidine, EFM, EIS, AFM, FTIR

\section{INTRODUCTION}

Brass is a combination of $\mathrm{Cu}$ and $\mathrm{Zn}$ in alloy which can be changed to variable mechanical and electrical properties [1]. It is a substitutional alloy: particles of the two constituents may replace each other inside the same crystal structure [2]; both brass and bronze may incorporate little extents of a range of different components containing lead, arsenic, phosphorus, silicon and manganese. The differentiation among the two alloys is to a great extent historical [3] and present-day practice in museums and archaeology studies progressively maintains a strategic distance from the two terms for historical objects in favor of the more general "copper alloy" [4]. The applicability of pharmaceutical compounds as Eco- friendly corrosion inhibitors for metals in acidic media has been recognize for a long time [5-19].

\footnotetext{
"Corresponding author

E-mail: asfouda@mans.edu.eg

Paper received: 30. 04. 2020.

Paper corrected: 14. 07. 2020.

Paper accepted: 22. 07. 2020.

Paper is available on the website: www.idk.org.rs/journal
}

Organic composites that mainly contains oxygen, sulphur, nitrogen atoms, and multiple bonds in the molecule are mostly utilize in industry for preventing dissolution through which they are adsorbed on metal surface [20-27]. Also, the utilized of drugs as a corrosion hindrance has been described [28-31]. Depending on type of force adsorption can be physisorption, chemisorption or a combination of both [32].

The main impartial of this research was to examine expired nizatidine drug, as a green inhibitor for brass dissolution in acidic medium due to existence of oxygen and nitrogen in its structure as active centers, high molecular size, nontoxic, and inexpensive all the pervious mentioned properties indicate that expired nizatidine drug is "Eco friendly" corrosion inhibitor. The dissolution behavior of $\alpha$-brass in acidic environment is a subject of pronounced practical importance considering its widespread applications

\section{EXPERIMENTAL TESTS}

\subsection{Materials and Solutions}

$\alpha$-brass sample with the composition (weight $\%$ ): $70 \% \mathrm{Cu}$ and $\mathrm{Zn} 30 \%$. Test materials 
were scratched with various emery papers equal to 1200 grade, clean with distilled water and properly dried prior to test. Analar grade $37 \% \mathrm{HCl}$ and distilled water were utilized to solution preparation. Chemical structure of nizatidine drug is presented in Fig. 1. nizatidine ((E)-1-N'-[2-[[2-[(dimethylamino) methyl]-1,3-thiazol-4-yl] methylsulfanyl] ethyl]-1-Nmethyl-2-nitroethene-1,1-diamine commonly used treatment of treatment of peptic ulcer disease. Nizatidine (molecular weight of 331.46 ) was utilized for the study.<smiles>CN/C(=C\[N+](=O)[O-])NCCSCc1csc(CN(C)C)n1</smiles>

Figure 1. Chemical structures of the nizatidine drug

Slika 1. Hemijske strukture leka nizatidina

\subsection{Weight Loss (WL) tests}

$(\mathrm{WL})$ is a method in which seven sample of brass with dimension of $2 \mathrm{~cm} \times 2 \mathrm{~cm} \times 1 \mathrm{~mm}$ are abraded well by emery papers that started with 300 and ended with 1200 grit size, rinsed with bidistilled water, degreased in acetone and dried, then weighed accurately. The (\% IE) is calculated by following equation [33].

$$
I E \%=\theta \times 100=\left[1-\left(W / W^{\circ}\right)\right] \times 100
$$

Where $\mathrm{W}^{\circ}$ and $\mathrm{W}$ values are $(\mathrm{WL})$ of blank and existence altered doses of nizatidine inhibitor, correspondingly

\subsection{Electrochemical tests}

\subsubsection{Potentiodynamic Polarization (PP) method}

In the present work, destructive (PP) and nondestructive methods (EIS, EFM) used to determine the dissolution of $\alpha$-brass. Three glass cells were utilized in this test. Before each test, (brass) samples were in the open system cleaned at $250 \mathrm{C}$ as in the (WL) method. (brass) probe washed, dried and placed in the test environment until it takes 1800 second to arrive the open circuit potential. The (PP) procedure is performed as before [33]. The potential was taking place from -800 to $+800 \mathrm{mV}$ vs (Eocp). An electrochemical solution potential is produced and the corrosion potential $\left(E_{\text {corr }}\right)$ and corrosion current $\left(i_{\text {corr }}^{\circ}\right)$ from the Tafel curves were measured from the extrapolating both cathodic and anodic Tafel lines. $\%$ IE is determined by Eq. (2) as follows:

$$
\% I E=\theta \times 100=\left[1-\left(i_{\text {corr }} / i_{\text {corr }}^{\circ}\right)\right] \times 100
$$

Where $\mathrm{i}_{\text {corr }}$ and $\mathrm{i}_{\text {corr }}$ are the current with and without nizatidine drug, individually

\subsubsection{Electrochemical Impedance Spectroscopy (EIS) tests}

EIS used AC signal in a frequency range of 100 $\mathrm{kHz}$ to $0.1 \mathrm{~Hz}$ during a $10-\mathrm{mV}$ peak-to-peak amplitude. All EIS data had fitted to suitable equivalent circuit utilizing the software version 6.03 for Gamry Echem calculation.

\subsubsection{Electrochemical Frequency Modulation (EFM) Measurements}

EFM can be utilize as a fast and good nondestructive method for (brass) independent Tafel slope corrosion. EFM Amplitudes $10 \mathrm{mV}$ to 2 and $5 \mathrm{~Hz}$ techniques [34-36]. High peak used for calculating current density $\left(\mathrm{i}_{\text {corr }}\right)$, Tafel slope $\left(\beta_{\mathrm{c}} \&\right.$ $\beta_{\mathrm{a}}$ ) and causal factors (CF-2 \& CF-3) [37].

Gamry Instruments Series (G750TM Potentiostat / Galvanostat / ZRA) implemented electrochemical methods with Gamry applications including software: DC 105, EIS300 for EIS and EFM140 for EFM. Echem analyst 6.03 software was utilized for drawing, graphing, and data fitting.

\subsection{Analysis of surface morphology}

2.4.1. Fourier transform infrared spectroscopy (FTIR) tests

FT.IR is carried out using Thermo Fisher Nicolet IS10, USA spectrophotometer in the region between 4500 and $500 \mathrm{~cm}^{-1}$

\subsubsection{Atomic Force Microscopy (AFM) analysis}

Surface examination of brass sample was examining utilizing (AFM) (Park systems, XE-100 model). After engagement in corrosive environment in the attendance and lack of the expired nizatidine drug inhibitor for $24 \mathrm{~h}$ at $25^{\circ} \mathrm{C}$.

\subsubsection{Scanning Electron Microscopy tests (SEM, EDX)}

Scanning Microscope Electron - type JOEL 840, Japan earlier and later dipping in corrosive environment in the existence and nonattendance of the $300 \mathrm{ppm}$ of the expired nizatidine drug at $25^{\circ} \mathrm{C}$, for 1 day, studied the electrode surface of brass.

\subsection{Quantum Chemical Calculations}

Theoretical studies have utilized to decide the relation among the structure of expired nizatidine drug and the effectiveness of corrosion inhibition. Therefore, PM3 semi empirical method is a very powerful test to study barrier-surface interaction, and to investigate investigational value 


\section{RESULTS AND DISCUSSION}

\subsection{WL tests}

The reduction in WL of $\alpha$-brass alloy can be studied in the presence of expired nizatidine drug at $25^{\circ} \mathrm{C}$. Figure (2) shows that expired nizatidine drug decreases the $\mathrm{WL}$ and therefore corrosion rate. The curves after $120 \mathrm{~min}$. begin to go to constancy, due to the formation of corrosion products on alloy surface. The (\%IE) and then $\theta$, of the expired nizatidine drug for the $\alpha$-brass were founded by eq. (1). The data of \%IE are given in Tables 1,2. From these tables, it is indicated that the IE\% was improved steadily with improving the dose of expired nizatidine drug and lowered with temperature rising from $25-45^{\circ} \mathrm{C}$.

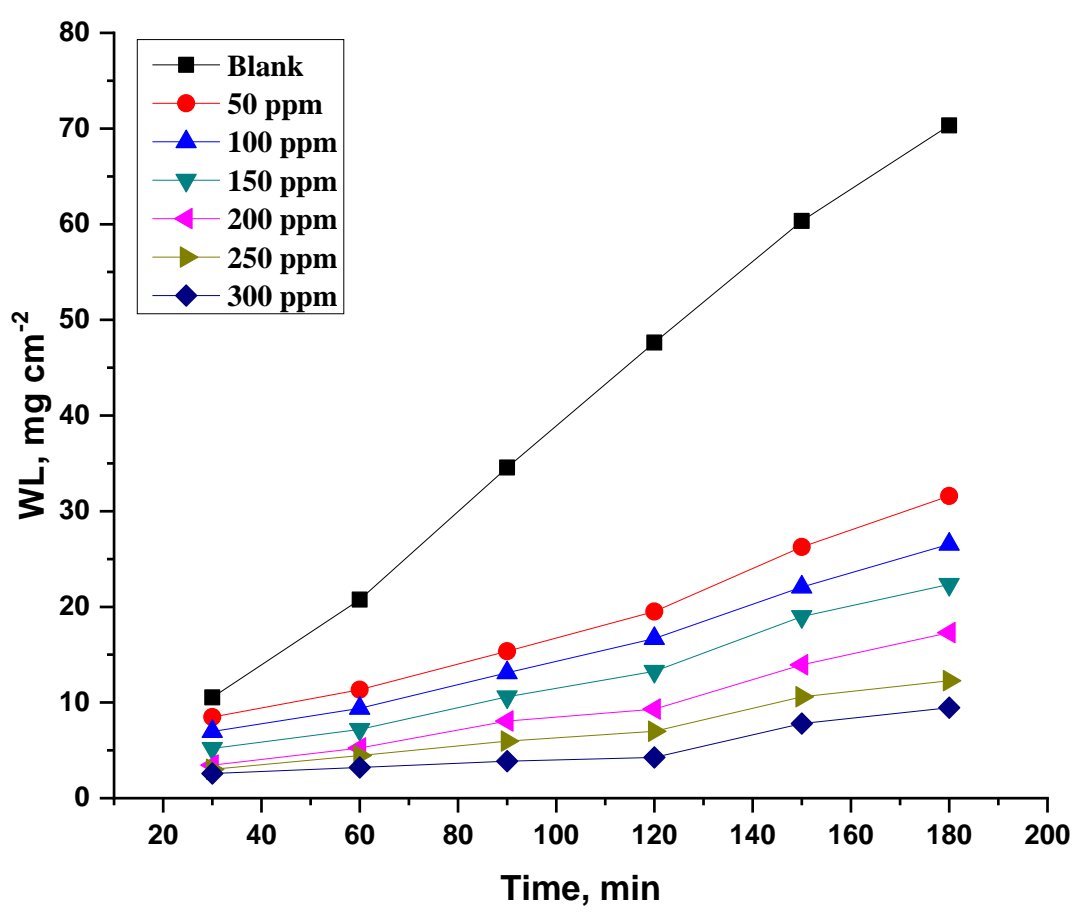

Figure 2. Time -WL curves for the dissolution of $\alpha$-brass in $1 \mathrm{M} \mathrm{HCl}$ with and without varied doses of expired nizatidine.

Slika 2. Kriva vreme-WL rastvaranja a-mesinga u $1 \mathrm{M} \mathrm{HCl}$ sa i bez različitih doza isteklog nizatidina

Table 1. \% IE and è of the used expired nizatidine in $1 \mathrm{M} \mathrm{HCl}$ at $25^{\circ} \mathrm{C}$, obtained from WL test

Tabela 1. \% IE i è korišćenog isteklog leka nizatidina u $1 \mathrm{M} \mathrm{HCl}$ na $25^{\circ} \mathrm{C}$, dobijen WL testom

\begin{tabular}{|c|c|c|c|}
\hline $\begin{array}{c}\text { Conc., } \\
\text { ppm }\end{array}$ & $\begin{array}{c}\mathrm{k}_{\text {corr }} \\
\mathrm{mg} \mathrm{cm}^{-2} \mathrm{~min}^{-1}\end{array}$ & è & $\% \mathrm{IE}$ \\
\hline Blank & 0.40 & ---- & ---- \\
\hline 50 & 0.16 & 0.602 & 60.2 \\
\hline 100 & 0.14 & 0.694 & 69.4 \\
\hline 150 & 0.11 & 0.772 & 77.2 \\
\hline 200 & 0.08 & 0.841 & 84.1 \\
\hline 250 & 0.06 & 0.901 & 90.1 \\
\hline 300 & 0.03 & 0.951 & 95.05 \\
\hline
\end{tabular}

\subsection{Effect of Temperature}

It was discovered that the IE diminishes with raising temperature yet at lower rate than in unprotected medium with expanding the dose of the nizatidine, as record in Table 5. The noted protection activity of the expired nizatidine drug could ascribed to the adsorption of their expired nizatidine drug on $\alpha$-brass interface. The coated film of the adsorbed atoms must have isolated the metal surface from the $a$-brass interface from the aggressive medium that limited the dissolution of the alloy by blocking of their corrosion sites and hence the corrosion rate decreases with raising efficiency as the doses were increased. \% IE lowering with raising the temperature indication the physical adsorption. 


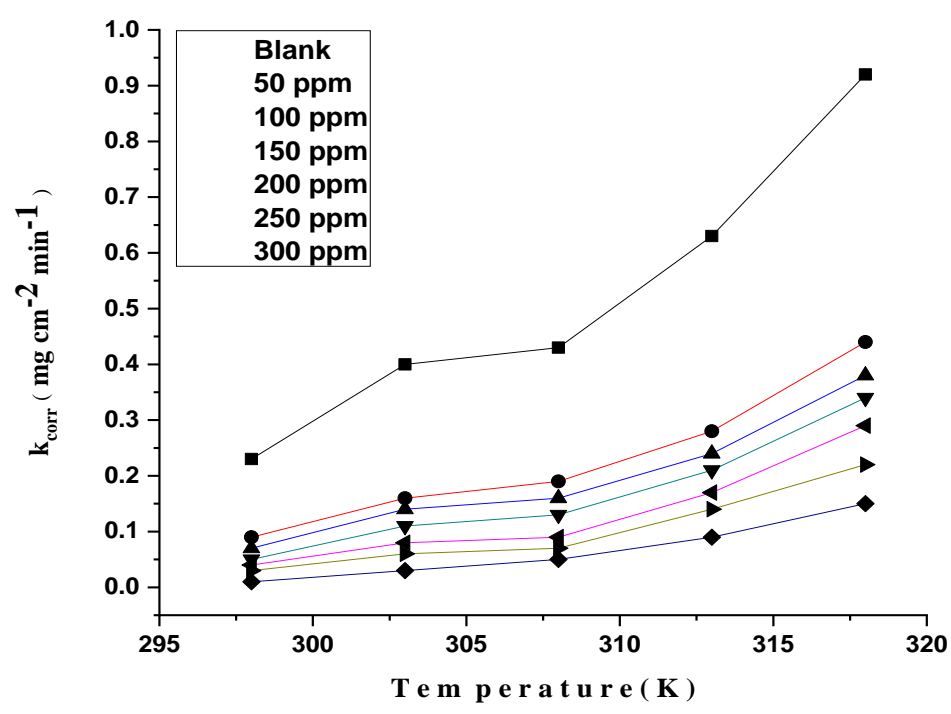

Figure 3. $k_{\text {corr }}$ vs. temperature for varies doses of expired nizatidine drug

Slika 3. Odnos $k_{\text {corr }} i$ temperature za različite doze isteklog leka nizatidina

Table 2. \% IE and $k_{\text {corr }}$ (in $\mathrm{mg} \mathrm{cm}^{-2} \mathrm{~min}^{-1}$ ) at various doses of expired nizatidine drug for the dissolution of $\alpha$ brass from WL tests at 25 to $45^{\circ} \mathrm{C}$

Tabela 2. \% IE i $k_{\text {cor }}\left(u \mathrm{mg} \mathrm{cm}^{-2} \mathrm{~min}^{-1}\right.$ ) kod različitih doza isteklog leka nizatidina za rastvaranje $\alpha$-mesinga iz WL testova na 25 do $45^{\circ} \mathrm{C}$

\begin{tabular}{|c|c|c|c|c|c|c|c|c|c|c|}
\hline \multirow{2}{*}{$\begin{array}{l}\text { [inh } \\
\text { ppm }\end{array}$} & \multicolumn{2}{|c|}{$25^{\circ} \mathrm{C}$} & \multicolumn{2}{c|}{$30^{\circ} \mathrm{C}$} & \multicolumn{2}{c|}{$35^{\circ} \mathrm{C}$} & \multicolumn{2}{c|}{$40^{\circ} \mathrm{C}$} & \multicolumn{2}{c|}{$45^{\circ} \mathrm{C}$} \\
\cline { 2 - 13 } & $\mathrm{k}_{\text {corr }}$ & $\% \mathrm{IE}$ & $\mathrm{k}_{\text {corr }}$ & $\% \mathrm{IE}$ & $\mathrm{k}_{\text {corr }}$ & $\% \mathrm{IE}$ & $\mathrm{k}_{\text {corr }}$ & $\%$ IE & $\mathrm{k}_{\text {corr }}$ & $\%$ IE \\
\hline Blank & 0.23 & --- & 0.40 & --- & 0.43 & --- & 0.63 & --- & 0.92 & -- \\
\hline 50 & 0.09 & 60.2 & 0.16 & 59.1 & 0.19 & 55.2 & 0.28 & 54.4 & 0.44 & 52.6 \\
\hline 100 & 0.07 & 69.4 & 0.14 & 65.0 & 0.16 & 63.1 & 0.24 & 62.4 & 0.38 & 58.9 \\
\hline 150 & 0.05 & 77.2 & 0.11 & 72.2 & 0.13 & 69.3 & 0.21 & 66.2 & 0.34 & 63.0 \\
\hline 200 & 0.04 & 84.1 & 0.08 & 80.4 & 0.09 & 78.3 & 0.17 & 73.0 & 0.29 & 68.9 \\
\hline 250 & 0.03 & 90.1 & 0.06 & 85.3 & 0.07 & 82.5 & 0.14 & 81.1 & 0.22 & 78.2 \\
\hline 300 & 0.01 & 95.05 & 0.03 & 92.0 & 0.05 & 90.1 & 0.09 & 88.2 & 0.15 & 85.1 \\
\hline
\end{tabular}

\subsection{Adsorption Isotherms}

Numerous isotherms equations were established by using adsorption isotherm regression analyses. It is evident that the Langmuir isotherm equation is the best fit equation to the results where the data of the regression coefficient $\left(R^{2}\right)$ approaches to unity. This behavior showed that the monolayer of adsorbed inhibitors has been formed on $\alpha$-brass interface according to the Langmuir equation (3) [38]

$$
C / \Theta)=1 / K_{a d s}+C
$$

Where the concentration of the nizatidine expressed as $C$, the adsorptive equilibrium constant expressed as $K$ and can be computed from the intercept of the difference among the $C / \theta$ and $C$ in Figure (4), the variation between $C / \theta$ and $\mathrm{C}$ where $\theta$ is the surface coverage, $=I E / 100$.

The $\Delta \mathrm{G}^{\circ}$ ads and $\mathrm{K}_{\mathrm{ads}}$ data are in Table (3). The $\Delta \mathrm{G}^{\circ}$ ads founded by:

$$
\Delta G^{\circ}{ }_{\text {ads }}=-R T \ln \left(55.5 K_{\text {ads }}\right)
$$

The nizatidine adsorption is spontaneous and this is proven by the $\Delta \mathrm{G}^{\circ}$ ads negative sign. From the data of $\Delta G^{\circ}$ ads (less than $-20 \mathrm{~kJ} \mathrm{~mol}^{-1}$ ), proven that the nizatidine adsorption is physically adsorbed. 


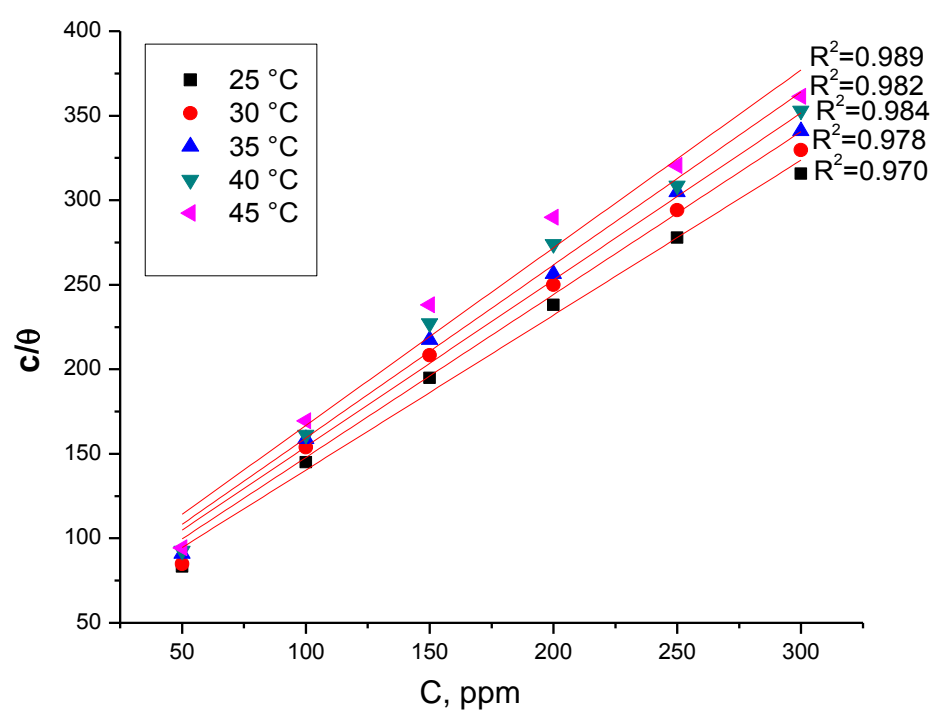

Figure 4. Langmuir diagrams for $\alpha$-brass in $1 \mathrm{M} \mathrm{HCl}$ at different temperatures

Slika 4. Lengmirove krive za $\alpha$-mesinga u $1 \mathrm{M} \mathrm{HCl} \mathrm{na} \mathrm{razlicitim} \mathrm{temperaturama}$

Table 3. Langmuir parameters of nizatidine drug at $25-45^{\circ} \mathrm{C}$

Tabela 3. Lengmirovi parametri za lek nizatidin na 25

do $45^{\circ} \mathrm{C}$
\begin{tabular}{|c|c|c|c|}
\hline $\begin{array}{c}\Delta \mathrm{G}^{\circ}{ }_{\text {ads, }}, \\
\mathrm{kJ} \mathrm{mo}^{-1}\end{array}$ & slope & $\mathrm{K}_{\text {ads, }} \mathrm{M}^{-1}$ & $\begin{array}{c}\text { Temp., } \\
{ }^{\circ} \mathrm{C}\end{array}$ \\
\hline 16.98 & 0.9866 & 20.5 & 25 \\
\hline 17.58 & 0.9941 & 19.4 & 30 \\
\hline 17.68 & 0.9871 & 18.0 & 35 \\
\hline 17.89 & 1.0231 & 17.5 & 40 \\
\hline 17.97 & 1.0116 & 16.2 & 45 \\
\hline
\end{tabular}

The thermodynamic basic equation can be used to measure $\Delta \mathrm{H}^{\circ}$ ads and $\Delta \mathrm{S}^{\circ}$ ads [39] expressed by:

$$
\Delta G^{o}{ }_{a d s}=\Delta H^{o}{ }_{a d s}-T \Delta S^{o}{ }_{a d s}
$$

Table 4. Parameters for nizatidine adsorbed on $\alpha$ brass interface in $1 \mathrm{M} \mathrm{HCl}$ at varied temperature

Tabela 4. Parametri za lek nizatidin adsorbovan na povrsinu $\alpha$-mesinga u $1 \mathrm{M} \mathrm{HCl}$ pri različitim temperaturama

\begin{tabular}{|c|c|c|c|}
\hline $\begin{array}{c}\text { Temp., } \\
{ }^{\circ} \mathrm{C}\end{array}$ & $\begin{array}{c}-\Delta \mathrm{G}^{\circ} \text { ads } \\
\mathrm{kJ} \mathrm{mol}^{-1}\end{array}$ & $\begin{array}{c}-\Delta \mathrm{H}^{\circ} \text { ads } \\
\mathrm{kJ} \mathrm{mol}^{-1}\end{array}$ & $\begin{array}{c}-\Delta \mathrm{S}^{\circ} \text { ads } \\
\mathrm{J} \mathrm{mol}^{-1} \mathrm{~K}^{-1}\end{array}$ \\
\cline { 1 - 2 } 25 & 16.98 & & \\
\cline { 1 - 2 } 30 & 17.58 & \multirow{2}{*}{51.6} & \multirow{2}{*}{156} \\
\cline { 1 - 2 } 35 & 17.68 & & \\
\cline { 1 - 2 } 40 & 17.89 & & \\
\cline { 1 - 2 } 45 & 17.97 & & \\
\hline
\end{tabular}

Figure 5 shows the relation between $\Delta \mathrm{G}^{\circ}$ ads and $T$. A negative sign of $\Delta S^{\circ}$ ads proved that the disorder of corrosion process is decreases by using nizatidine (Table 4)

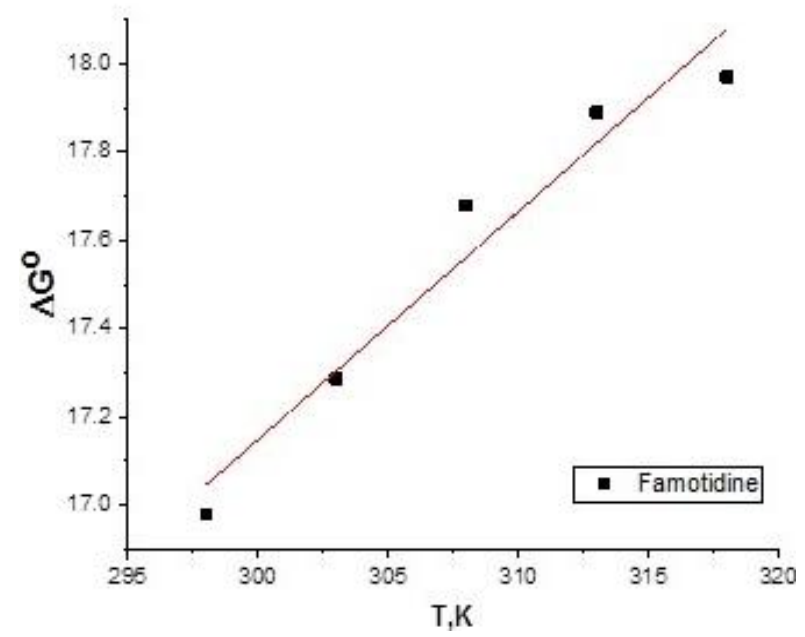

Figure 5. $\Delta G^{\circ}{ }_{\text {ads }} v s$. $T$ for the adsorption of nizatidine drug at varied temperatures

Slika 5. Odnos $\Delta G^{\circ}$ ads vs. $T$ za adsorpciju leka nizatidina pri različitim temperaturama

3.4. Kinetic-thermodynamic corrosion parameters

The Arrhenius Eq. (6):

$$
k_{\text {corr }}=A \exp \left(E^{*} a / R T\right)
$$

Where $A$ is Arrhenius constant and $E_{a}{ }^{*}$ is the activation energy [40]. Figure 6 refers to the straight lines given by a plot [log $k_{\text {corr }}$ vs. $\left.1 / T\right]$, which 
can be calculate the $E_{a}^{*}$ from their slopes which illustrated in Table 5.

$$
k_{\text {corr }}=(R T / N h) \exp \left(\Delta S^{*} / R\right) \exp \left(-\Delta H^{*} / R T\right)
$$

Where $\Delta S^{*}$ and $\Delta H^{*}$ are entropy and activation enthalpy [41]. Plot [log $k_{\text {corr }} / \mathrm{T}$ vs. $\left.1 / \mathrm{T}\right]$ from their slopes $\Delta H^{*}$ and their intercepts $\Delta S^{*}$ can be measured and documented in Figure 7 and Table 5. The outcome data designate that $E_{a}{ }^{*}$ increase in the existence of expired nizatidine drug than in its nonattendance, representative physical adsorption, significance that the block of $\alpha$-brass surface activities by from protected film and inhibiting. However, the value of $\left(\Delta S^{*}\right)$ lowered gradually with raising expired nizatidine drug dose in all the acidic solution

Table 5. Activation data for $\alpha$-brass corrosion without and with altered doses of expired nizatidine drug in $1 \mathrm{M} \mathrm{HCl}$

Tabela 5. Podaci o aktivaciji korozije $\alpha$-mesinga bez i sa izmenjenim dozama isteklog leka nizatidina u $1 \mathrm{M} \mathrm{HCl}$

\begin{tabular}{|c|c|c|c|}
\hline $\begin{array}{c}{\left[\begin{array}{l}\mathrm{inh}] \\
\mathrm{pmm}\end{array}\right.} \\
\text { Blank }\end{array}$ & $\begin{array}{c}\mathrm{E}_{\mathrm{a}}^{*} \\
\mathrm{~kJ} \mathrm{~mol}^{-1}\end{array}$ & $\begin{array}{c}\Delta \mathrm{H}^{*} \\
\mathrm{~kJ} \mathrm{~mol}^{-1}\end{array}$ & $\begin{array}{c}-\Delta \mathrm{S}^{*} \\
\mathrm{~J} \mathrm{~mol}^{-1} \mathrm{~K}^{-1}\end{array}$ \\
\hline 50 & 50.9 & 48.3 & 94.5 \\
\hline 100 & 64.7 & 61.2 & 85.4 \\
\hline 150 & 69.2 & 66.1 & 80.5 \\
\hline 200 & 72.2 & 69.5 & 78.6 \\
\hline 250 & 74.5 & 72.3 & 70.5 \\
\hline 300 & 81.2 & 79.3 & 68.1 \\
\hline & 85.6 & 81.2 & 65.4 \\
\hline
\end{tabular}

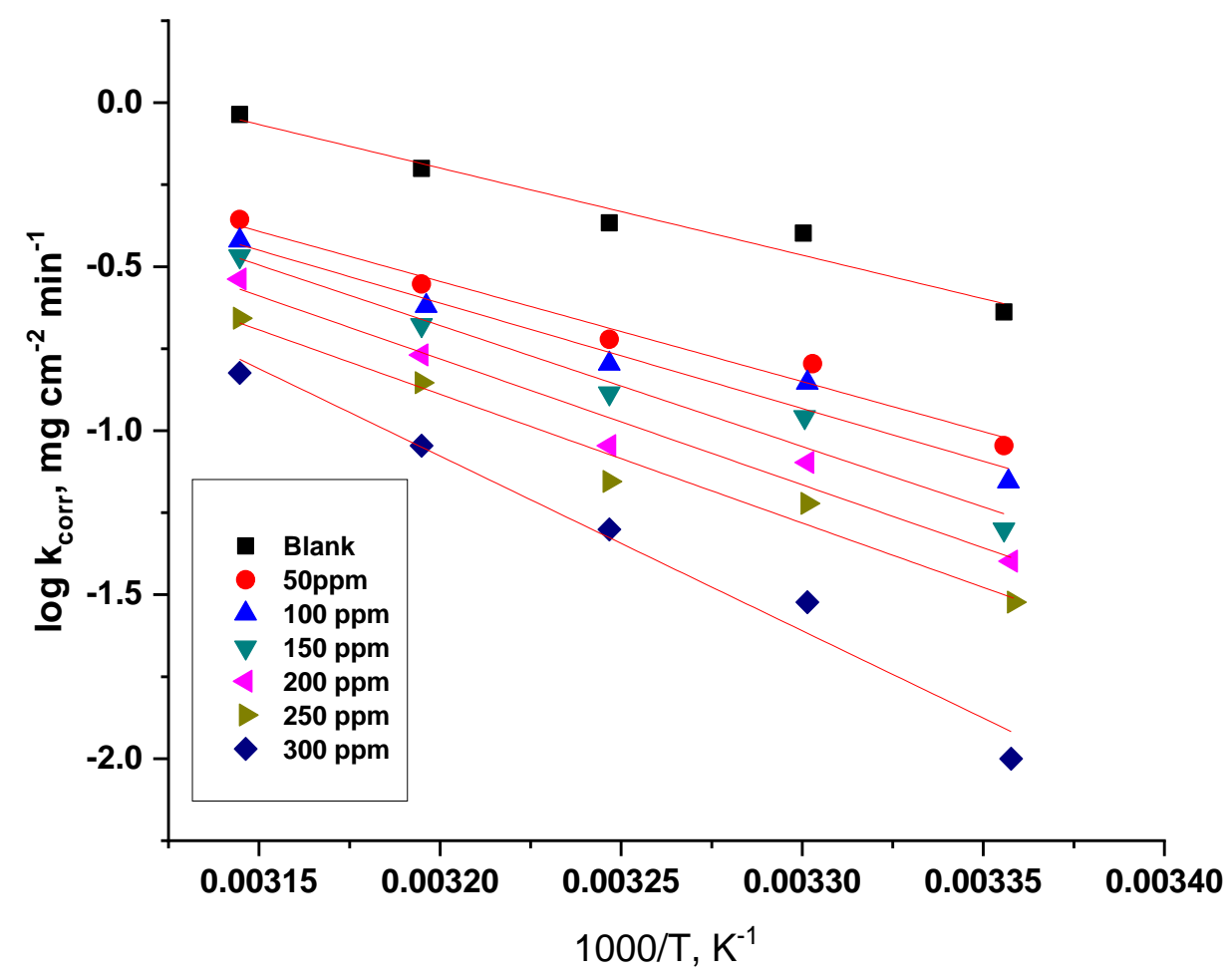

Figure 6. Plotting the Arrhenius of Log $\left(k_{\text {corr }}\right)$ vs. $(1 / \mathrm{T})$ for dissolution of $\alpha$-brass in $1 \mathrm{M} \mathrm{HCl}$ solution with and without various doses of expired nizatidine drug at altered temperatures.

Slika 6. Arrheniusove krive o Log kcorr vs $(1 / \mathrm{T})$ za rastvaranje $\alpha$-mesinga u rastvoru $1 \mathrm{M} \mathrm{HCl}$ sa i bez različitih doza isteklog leka nizatidina na razlicitim temperaturama. 


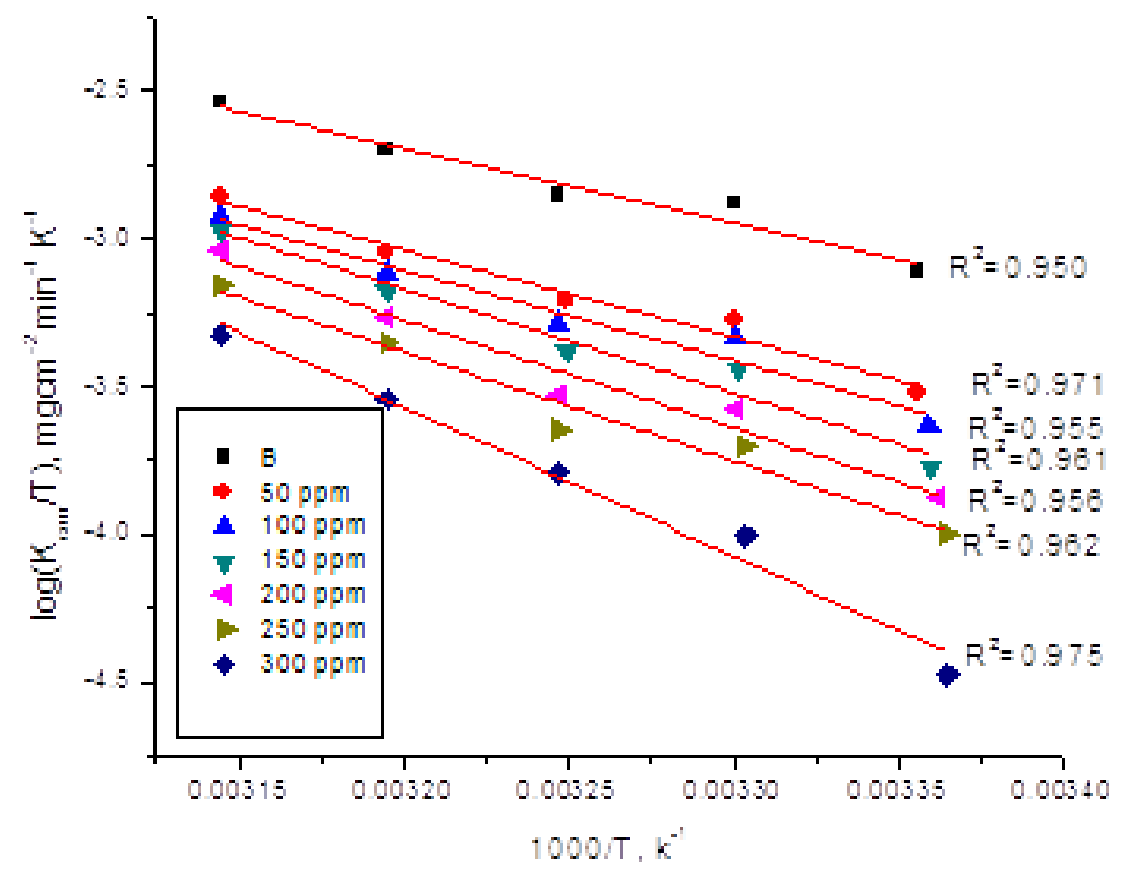

Figure 7. Plotting Log $\left(k_{\text {corr }} / T\right)$ vs. $(1 / T)$ for dissolution of $\alpha$-brass in $1 \mathrm{M} \mathrm{HCl} \mathrm{solution} \mathrm{in} \mathrm{without} \mathrm{and} \mathrm{with} \mathrm{of}$ various doses of expired nizatidine drug at altered temperatures.

Slika 7. Krive Log (kcorr / T) vs. (1/T) za rastvaranje $\alpha$-mesinga u rastvoru $1 \mathrm{M} \mathrm{HCl} \mathrm{bez} \mathrm{i} \mathrm{sa} \mathrm{raznim}$ dozama isteklog leka nizatidina na razlicitim temperaturama

\subsection{Polarization $(P P)$ measurements}

Figure 8 demonstrations PP bends registered for brass in $1 \mathrm{M} \mathrm{HCl}$ attendance and lack of altered dose of expired nizatidine at $25^{\circ} \mathrm{C}$. With the rise of the dose of nizatidine the curves move both anodic and cathodic sections to the lesser data of current densities which chief lowering in the $\mathrm{k}_{\text {corr }}$. The PP result in Table 6 . Variation of the data of $\left(\log \mathrm{i}_{\text {corr }}\right)$ with $\left(E_{c o r r}\right),\left(\beta_{\mathrm{a}}, \beta_{\mathrm{c}}\right)$, the rate of corrosion $\left(\mathrm{k}_{\mathrm{corr}}\right),(\theta)$ and $(\% \mathrm{IE})$. This means that both reactions of $\alpha$ - brass are retarded by expired nizatidine drug in acidic environment. $\beta_{\mathrm{a}}$ and $\beta_{\mathrm{c}}$, were smaller different with the increasing the dose of expired nizatidine. This indicates that expired nizatidine drug signifies as mixed kind [42] The both anodic and cathodic constants didn't exchange essentially with increment in expired nizatidine drug dose, recommending that the existence of the expired nizatidine drug doesn't modify the reaction mechanism.

Table 6. Parameters obtained from PP tests of $\alpha$-brass for expired nizatidine drug

Tabela 6. Parametri dobijeni iz PP testova za $\alpha$-mesinga za istekli lek nizatidin

\begin{tabular}{|c|c|c|c|c|c|c|}
\hline $\begin{array}{l}\text { [inh] } \\
\text { ppm }\end{array}$ & $\begin{array}{c}\mathrm{i}_{\text {corr }} \\
\mu \mathrm{A} / \mathrm{cm}^{2}\end{array}$ & $\begin{array}{c}-E_{\text {corr }} \\
m V\end{array}$ & $\begin{array}{c}\hat{a}_{a} \\
m V / d e c a d e\end{array}$ & $\begin{array}{c}\hat{a}_{c} \\
\mathrm{mV} / \text { decade }\end{array}$ & $\mathrm{k}_{\text {corr }}$ & IE (\%) \\
\hline blank & 411 & 539 & 89 & 128 & 187.1 & ---- \\
\hline 100 & 108 & 510 & 106 & 146 & 44.1 & 73.7 \\
\hline 150 & 84 & 518 & 110 & 148 & 37.9 & 79.6 \\
\hline 200 & 63 & 515 & 103 & 121 & 30.5 & 84.7 \\
\hline 250 & 39 & 508 & 98 & 128 & 22.3 & 90.5 \\
\hline 300 & 22 & 470 & 83 & 118 & 15.5 & 94.6 \\
\hline
\end{tabular}




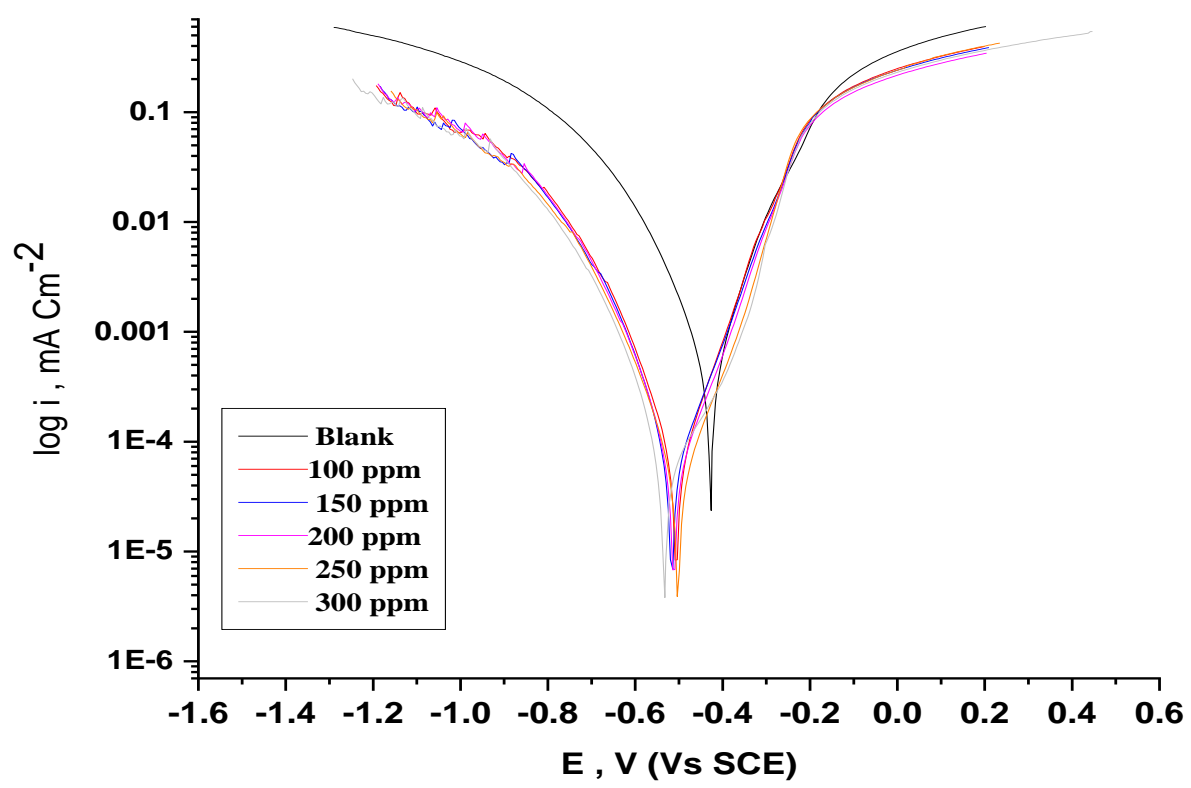

Figure 8. PP bends for dissolution of $\alpha$-brass in attendance and nonattendance of altered concentration of expired nizatidine at $25^{\circ} \mathrm{C}$

Slika 8. PP krive za rastvaranje $\alpha$-mesinga u prisustvu i odsustvo izmenjene koncentracije isteklog leka nizatidina na $25^{\circ} \mathrm{C}$

\subsection{Electrochemical impedance spectroscopy}

\section{(EIS) tests}

The EIS parameters were analyze by fitting the equivalent circuit model displayed in Figure 9, which fits well with the experimental data. Figure 10(a, b) demonstration EIS (Nyquist and bode) in 1 $\mathrm{M} \mathrm{HCl}$ solutions with and without nizatidine drug at $25^{\circ} \mathrm{C}$. The values of $R_{c t}, C_{d l}$ and the $I E \%$ were gotten and recorded in Table 7 . The decrease in $\mathrm{C}_{\mathrm{dl}}$ is a consequence of a lower in local dielectric constant and/or improve in the double layer thickness. The corresponding Rct was also used to calculate IE and CPE which is utilized to describe the double layer [43]:

$$
C_{d l}=Y_{0}\left(\omega_{\max }\right)^{n-1}
$$

Where $\omega_{\max }=2 \pi f_{\max }, f_{\max }$ is the frequency of the highest imaginary value. The impedance, $Z$, associated with CPE is described as follows [44]:

$$
Z_{C P E}=Q^{-1}(j \varpi)^{-}
$$

Where $Q$ stand for the CPE constant and exponent, respectively. The factor $n$ (exponent) is an adjustable parameter that usually lies among 0.50 and 1.0 [45].

For $n=0, Z_{C P E}$ represents a resistance with $\mathrm{R}=$ $Q^{-1}$, for $n=1$, a capacitance with $C=Q$ for $n=0.5$, a Warburg element with $W=Q$ and for $n=-1$, an inductance with $L=Q^{-1}$

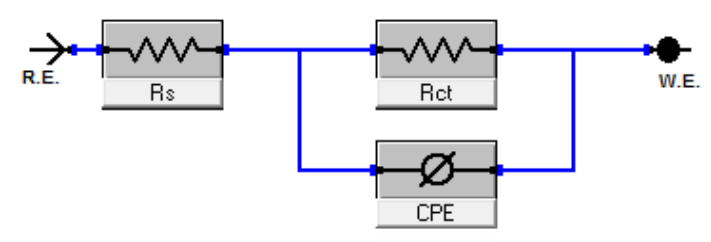

Figure 9. Equivalent electrochemical circuit model

Slika 9. Ekvivalentni elektrohemijski model kruga

The value gotten from the equivalent circuit are display in Table 7. The data display that $R_{\mathrm{ct}}$ data were improve by appending the nizatidine drug. Because the creation of an insulating coating film at the surface brass/solution. Alternatively, $\mathrm{C}_{\mathrm{dl}}$ data lowered, signifying that the nizatidine drug are adsorbed at the interface between brass/solution [46]. Nizatidine drug adsorbed on the bras surface lowered the electrical capacity for the reason they displace the water molecules by nizatidine drug adsorbed on the brass interface. The \% IE was measured from eq. 10 [47]:

$$
\% I E_{E I S}=\left[1-\left(R_{c t}^{\circ} R_{c t}\right)\right] \times 100
$$

where $R_{c t}^{0}$ and $R_{c t}$ are the resistance data attendance and lack of expired nizatidine drug individual. 


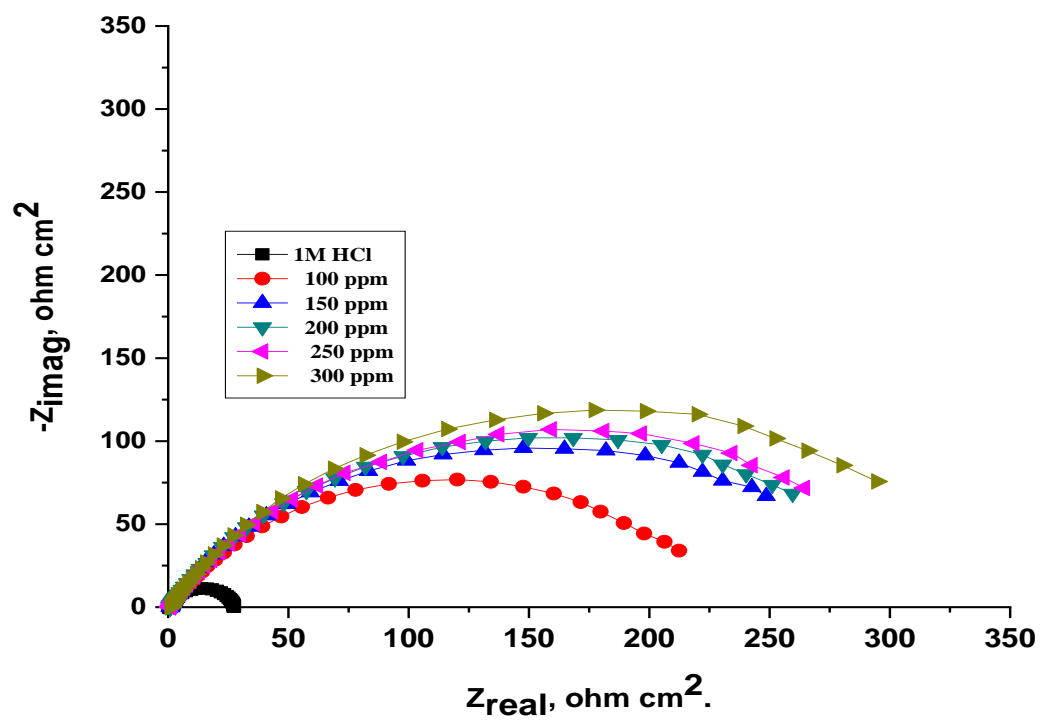

Figure 10 a. The Nyquist bends for dissolution of $\alpha$-brass existence and nonexistence various doses of the expired nizatidine drug

Slika 10 a. Nyquist krive rastvaranja $\alpha$-mesinga sa i bez različitih doza isteklog leka nizatidina

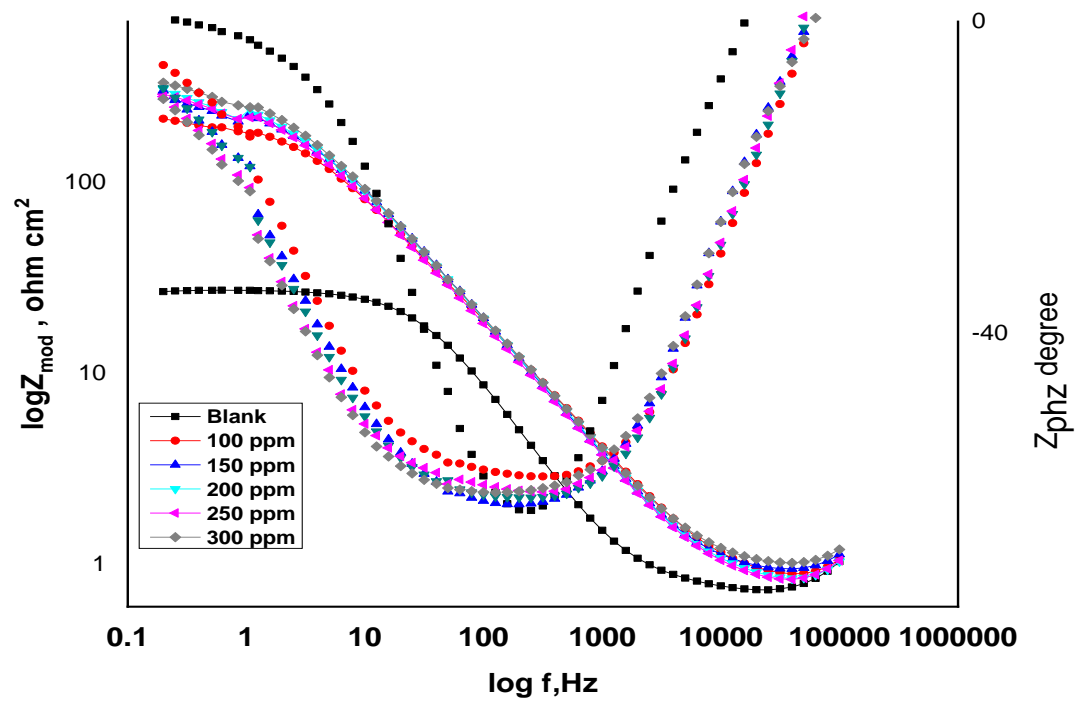

Figure $10 \mathrm{~b}$. Bode diagram plots for dissolution of $\alpha$-brass in $1 \mathrm{M} \mathrm{HCl}$ without and with various doses of the expired nizatidine drug at $25^{\circ} \mathrm{C}$

Slika 10 b. Sheme Bode dijagrama za rastvaranje $\alpha$-mesinga u $1 \mathrm{M} \mathrm{HCl}$ bez i sa različitim dozama isteklog leka nizatidina na $25^{\circ} \mathrm{C}$

Table 7: EIS data for $\alpha$-brass in $1 \mathrm{M} \mathrm{HCl}$ with and without various doses of the expired nizatidine drug at $25^{\circ} \mathrm{C}$

Tabela 7. Podaci EIS-a za $\alpha$-mesing u $1 \mathrm{M} \mathrm{HCl}$ sa i bez različitih doza isteklog leka nizatidina pri $25^{\circ} \mathrm{C}$

\begin{tabular}{|c|c|c|c|c|c|}
\hline$\% \mathrm{IE}$ & $\theta$ & $\mathrm{n}$ & $\mathrm{C}_{\mathrm{dl}}, \mu \mathrm{F} \mathrm{cm}$ & $\mathrm{R}_{\mathrm{ct}}, \Omega \mathrm{cm}^{2}$ & Conc., $\mathrm{M}$ \\
\hline--- & --- & 0.741 & 300 & 30.5 & $\mathrm{~B}$ \\
\hline 75.4 & 0.754 & 0.885 & 201 & 119.2 & 100 \\
\hline 80.4 & 0.804 & 0.891 & 177 & 178.3 & 150 \\
\hline 85.8 & 0.858 & 0.944 & 120 & 212.2 & 200 \\
\hline 91.2 & 0.918 & 0.976 & 100 & 333.1 & 250 \\
\hline 93.0 & 0.930 & 0.940 & 80 & 440.1 & 300 \\
\hline
\end{tabular}




\subsection{Electrochemical frequency modulation (EFM)} tests

The EFM curves for expired nizatidine drug in $1 \mathrm{M} \mathrm{HCl}$ solution at $25{ }^{\circ} \mathrm{C}$ attendance and nonattendance altered dose of $(100-300 \mathrm{ppm})$ expired nizatidine drug had listed and presented in Figure 11. (EFM) can used to measure the corrosion current directly in which two waves (at different frequencies) have meanwhile been bound to the cell [48]. The data in Table 8 are derived from Figure 11, which indicates that the current of liquefaction lowered with an increment in the doses of expired nizatidine drug, and thus (IE\%) increases. The largest peaks were utilized to measure the ( $\left.i_{\text {corr }}\right),\left(\beta_{c}\right.$ and $\left.\beta_{a}\right)$ and the causality factors (CF-2 and CF-3). CF-2 and CF-3 are utilized to checkered on the validity of EFM methods and are determine from the EFM are equal nearly to the theoretical value (2 and 3 ) representative that the value is verified and of excellent quality [49].
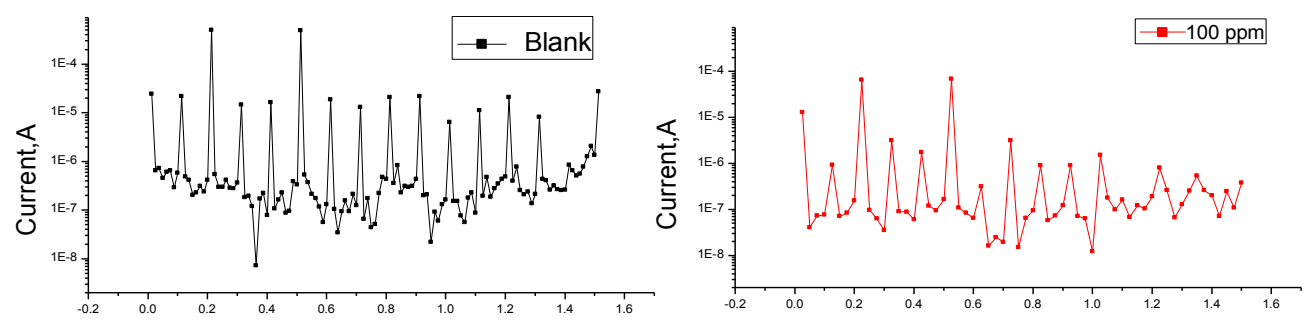

Frequency, $\mathrm{HZ}$
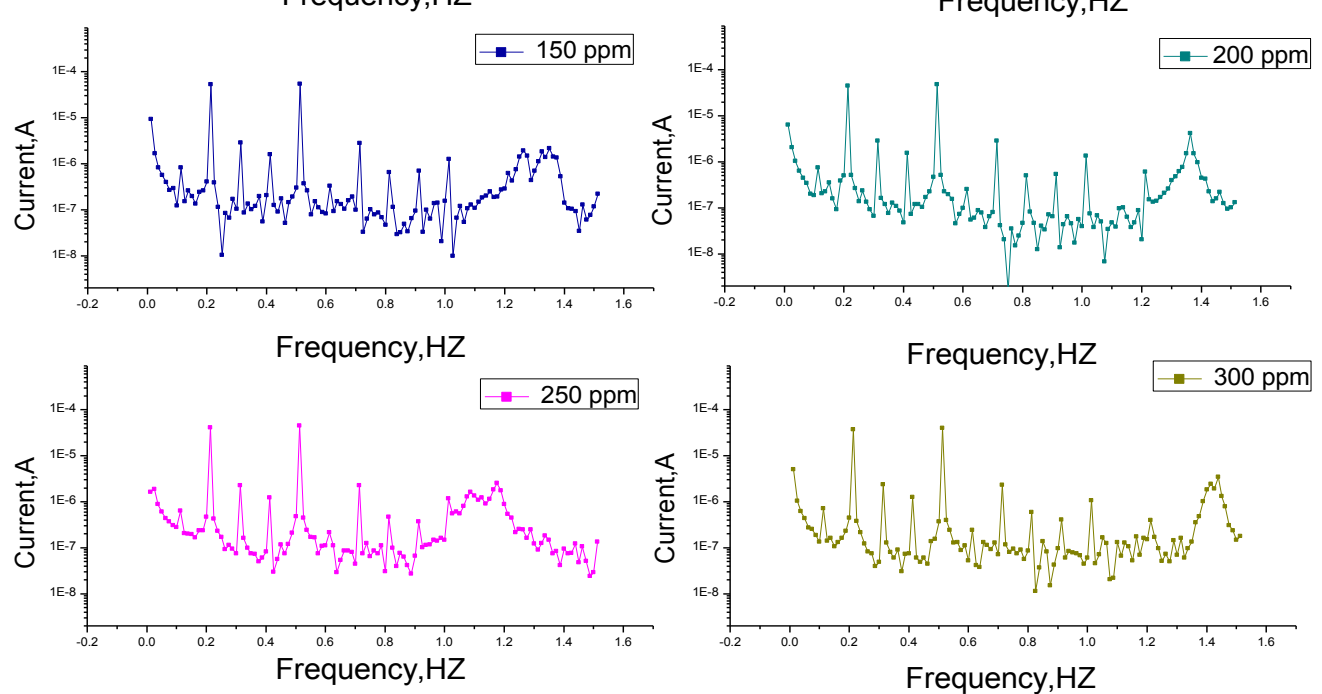

Figure 11 (a-f). EFM spectra for the dissolution of $\alpha$-brass with and without various doses of expired nizatidine drug

Slika 11 a-f. EFM spektri za rastvaranje $\alpha$-mesinga sa i bez različitih doza isteklog leka nizatidina

Table 8. Parameters gotten from EFM technique for various doses of nizatidine drug at $25^{\circ} \mathrm{C}$

Tabela 8. Parametri dobijeni iz EFM tehnike za različite doze leka nizatidina na $25^{\circ} \mathrm{C}$

\begin{tabular}{|c|c|c|c|c|c|c|c|c|}
\hline $\begin{array}{c}\text { Conc, } \\
\mathrm{ppm}\end{array}$ & $\mathrm{i}_{\text {corr }, \mu \mathrm{A}}$ & $\begin{array}{c}\beta_{\mathrm{a}} \\
\mathrm{mV} \mathrm{dec}\end{array}$ & $\begin{array}{c}\beta_{\mathrm{c}} \\
\mathrm{mV} \mathrm{dec}^{-1}\end{array}$ & $\begin{array}{c}\mathrm{k}_{\text {corr. }} \\
\mathrm{mpy}\end{array}$ & CF-2 & CF-3 & $\theta$ & $\% \mathrm{IE}$ \\
\hline Blank & 256.3 & 36.8 & 64.9 & 124.4 & 1.65 & 2.84 & & \\
\hline 100 & 55.4 & 90.7 & 109.9 & 27.1 & 1.50 & 3.25 & 0.787 & 78.7 \\
\hline 150 & 35.7 & 99.1 & 105.0 & 18.2 & 2.45 & 3.04 & 0.852 & 85.2 \\
\hline 200 & 32.7 & 100.9 & 118.2 & 16.2 & 2.11 & 3.11 & 0.875 & 87.5 \\
\hline 250 & 28.1 & 110.6 & 116.3 & 14.1 & 2.44 & 3.77 & 0.893 & 89.3 \\
\hline 300 & 26.8 & 122.3 & 103.6 & 9.5 & 2.35 & 3.20 & 0.933 & 93.3 \\
\hline
\end{tabular}




\section{8. (FTIR) analysis}

Figure 12 demonstrations the FTIR of the pure expired nizatidine drug and metal surface. Figure 12 (a) show the band at $3332 \mathrm{~cm}^{-1}$ demonstrations $\mathrm{OH}$ frequency. The FTIR spectra of the protective film found on the a-brass interface after rinsing in solution including $300 \mathrm{ppm}$ of expired nizatidine drug is display in Figure 12(b) the $\mathrm{OH}$ seemed at
$3356 \mathrm{~cm}^{-1}$. This exchange is instigating by the density of electron cloud from the $O$ atom to $\alpha$ brass. This recommends that the $\mathrm{O}$ atom of the expired nizatidine drug is coordinated to a-brass. The band at $1651 \mathrm{~cm}^{-1}$ is $\mathrm{C}-\mathrm{C}$ stretching of alkene non-conjugated on the interface of $\alpha$-brass film that raised from $1622 \mathrm{~cm}^{-1}$ of pure nizatidine drug.

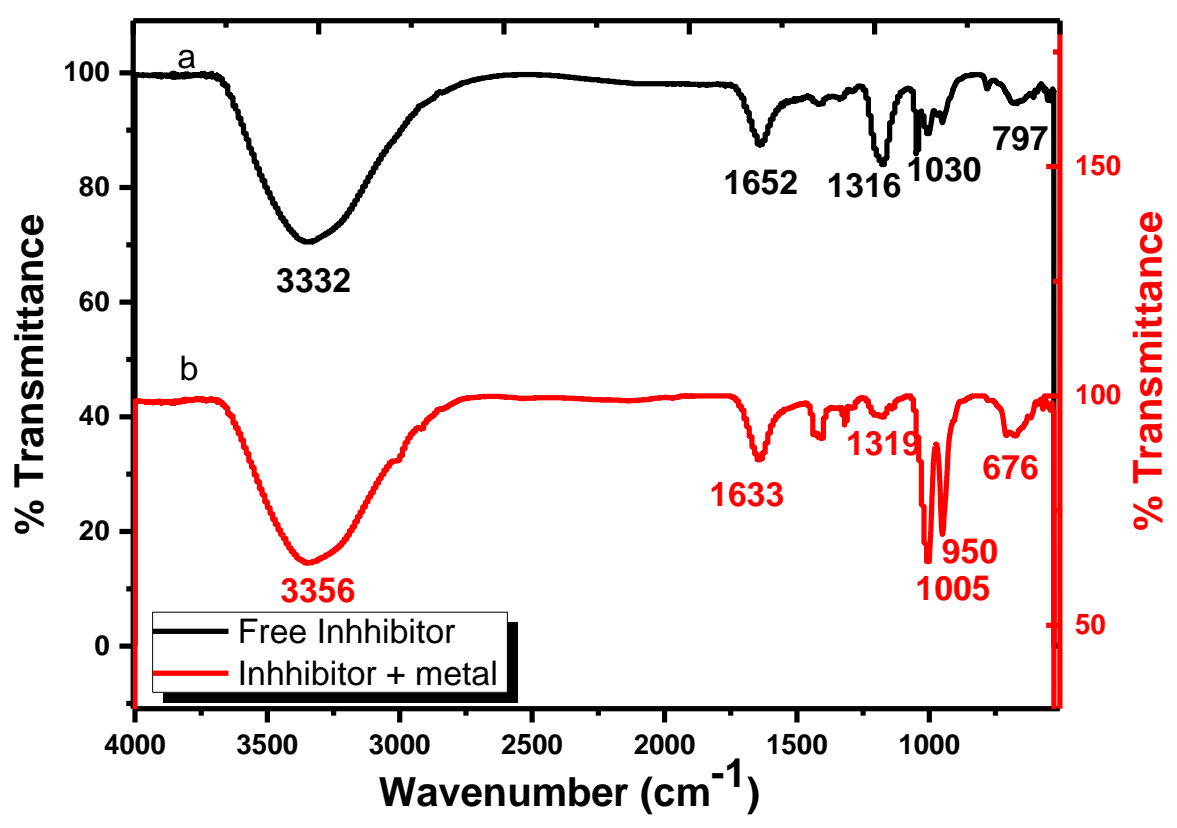

Figure 12. FT-IR spectra of expired nizatidine drug (a) black spectrum line and formed film of expired nizatidine drug on $\alpha$-brass surface (b) the red spectrum line

Slika 12. FT-IR spectri isteklog nizatidinskog leka (a) crna linija spektra i formiran film isteklog leka nizatidina na površini $\alpha$-mesinga (b) crvena linija spectra

\subsection{AFM analysis}

This method gives a map about the $\alpha$-brass interface where roughness is indicating with an excessive resolve [50]. The 3D images of AFM shown in Figure 13.

The roughness calculated from the AFM image have summarized in Table 9. From the table, the surface of the alpha brass is smoother than in the existence of the expired nizatidine drug due to the expired nizatidine drug adsorption therefore the acid attack is reduced
Table 9. AFM data for $\alpha$-brass interface attendance and lack expired nizatidine.

Tabela 9. AFM podaci za prisustvo a-mesinga $i$ nedostatak isteklog nizatidina.

\begin{tabular}{|l|c|}
\hline Sample & $\begin{array}{c}\text { Average roughness (Sa) } \\
\mathrm{nm}\end{array}$ \\
\hline Free & 15 \\
\hline Blank & 302 \\
\hline Expired nizatidine & 37 \\
\hline
\end{tabular}




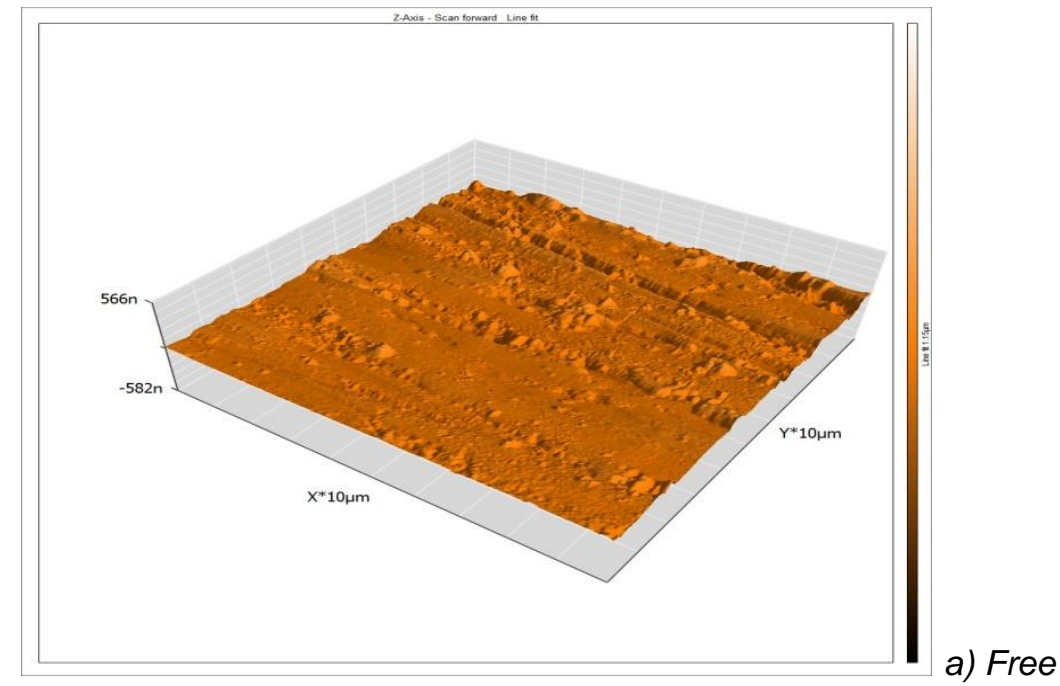

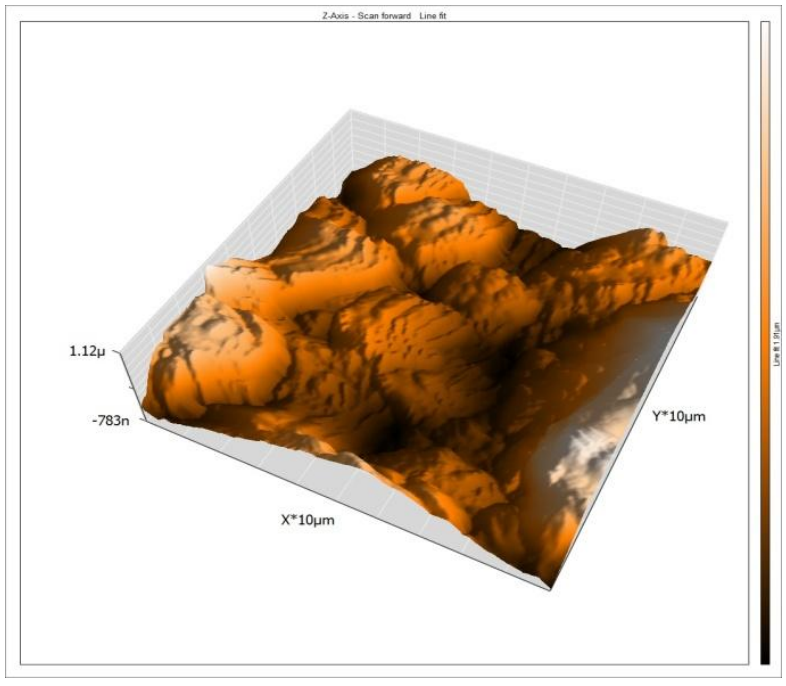

b) Blank

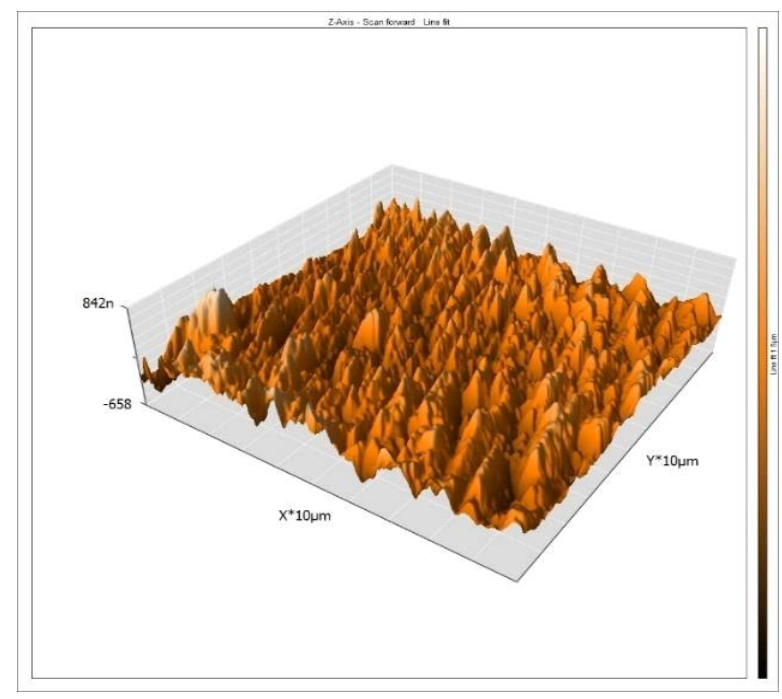

c) 300 ppm expired nizatidine drug

Figure 13. (3D) AFM images of $\alpha$-brass without acid a) (free), $\alpha$-brass in $1 M \mathrm{HCl}$ b) (blank), and c) $\alpha$-brass in $1 \mathrm{M} \mathrm{HCl}+300$ ppm of expired nizatidine drug for 24 hours at $25^{\circ} \mathrm{C}$

Slika 13. (3D) AFM slike a-mesinga bez kiseline a) (slobodan), a-mesing u 1 M HCl b) (prazan) i c) $\alpha$ mesing u $1 \mathrm{M} \mathrm{HCl}+300$ ppm isteklog leka nizatidina tokom 24 sata na $25^{\circ} \mathrm{C}$

\subsection{Energy Dispersion Spectroscopy (EDX)} Studies

Fig. (14.a) shows the EDX examination result on the composition of $\alpha$-brass with and without expired nizatidine drug. The EDX examination titles that only $\mathrm{Fe}$ and $\mathrm{O}$ were identified, which indicate that the passive film includes only $\mathrm{Fe}_{2} \mathrm{O}_{3}$. Fig. (14.b) EDX examination of $\alpha$-brass in $1 \mathrm{M} \mathrm{HCl}$ only and Fig. (14.c) displays the EDX of $\alpha$-brass in $1 \mathrm{M}$ $\mathrm{HCl}$ in the presence of $300 \mathrm{ppm}$ of expired nizatidine drug. The spectrum shows attached lines, indicating the presence of $\mathrm{Cu}$ (owing to the copper atoms of expired nizatidine). These result shows that the $\mathrm{Cu}$ and $\mathrm{Zn}$ metals covered the $\alpha$ brass.
Table 10 shows weight \% composition of $\alpha$ brass after dipping in 24 hours in $\mathrm{HCl}$ with and without drug nizatidine.

Table 10. Weight \% of $\alpha$-brass after $24 \mathrm{~h}$ of dipping in $1 \mathrm{M} \mathrm{HCl}$ with and without $300 \mathrm{ppm}$ of the nizatidine drug

Tabela 10. Težina\% $\alpha$-mesinga nakon 24 sata uranjanja u $1 \mathrm{M} \mathrm{HCl}$ sa i bez 300 ppm nizatidin leka

\begin{tabular}{|l|c|c|c|c|c|}
\hline Mass (\%) & $\mathrm{Cu}$ & $\mathrm{Zn}$ & $\mathrm{Fe}$ & $\mathrm{C}$ & $\mathrm{O}$ \\
\hline Free & 60.78 & 32.72 & 0.79 & 3.48 & 1.13 \\
\hline Blank & 54.57 & 25.78 & 0.78 & 10.41 & 7.85 \\
\hline Nizatidine & 42.5 & 22.3 & -- & 30.2 & 13.1 \\
\hline
\end{tabular}



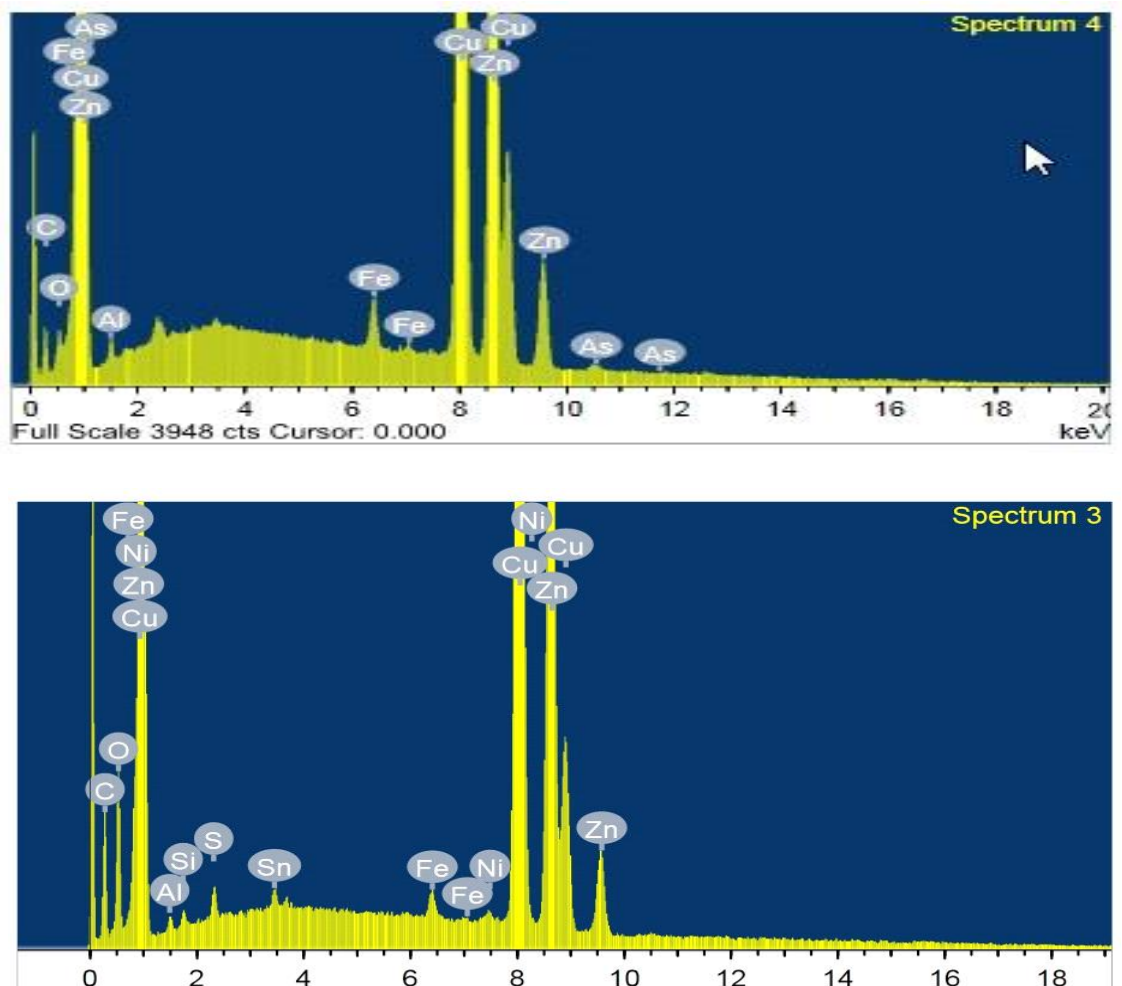

Full Scale $3111 \mathrm{cts}$ Cursor: 0.000

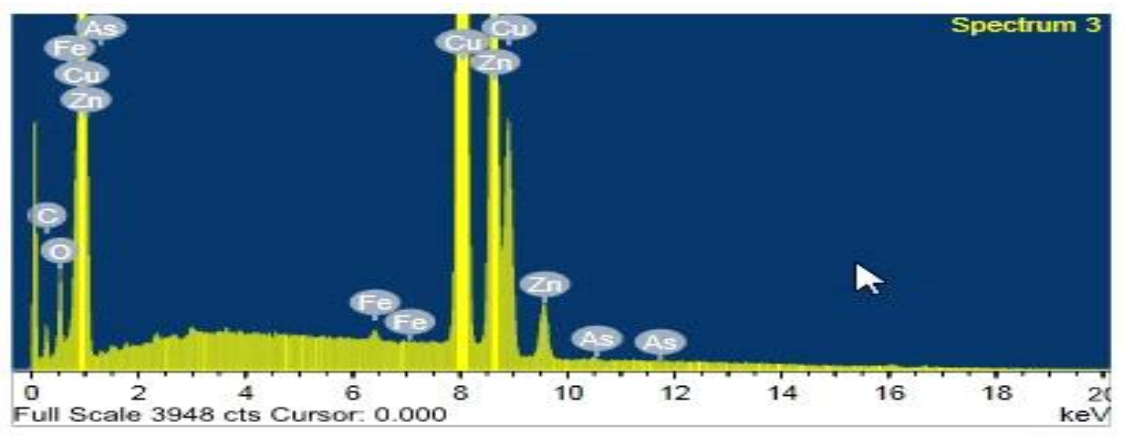

(c)

Figure (14) (a) EDX on $\alpha$-brass (free) (b) $\alpha$-brass in $1 \mathrm{M} \mathrm{HCl}$ (blank) (c) $\alpha$-brass in $1 \mathrm{M} \mathrm{HCl}$ with the presence of 300 ppm of expired nizatidine drug

Slika 14. (a) EDX za a-mesing (slobodan) (b) a-mesing u $1 \mathrm{M} \mathrm{HCl}$ (prazan) (c) $\alpha$-mesing u $1 \mathrm{M} \mathrm{HCl} \mathrm{sa}$ prisustvom 300 ppm isteklog nizatidin leka

\section{QUANTUM CHEMICAL CALCULATIONS}

The energy of frontier molecular orbitals can be associated with the reactivity of compounds and the corrosion inhibitive power of inhibitors [51]. The obtained data given in Table 11 such as LUMO and HOMO forms ( $E_{\text {HOMO }}$ and $E_{\text {LUMO }}$ ) and energy gap $\Delta \mathrm{E}$ are the output of the DFT calculations. Generally, the inhibitor's active power is always associated with $E_{\text {HOMO }}$ and $E_{\text {LUMO }}$ [52]. Higher adsorption can be indicating from the higher value of $\mathrm{E}_{\mathrm{HOMO}}$, which means higher capacity of inhibitors to donate electrons in certain chemical interaction. Whereas, the low values of $E_{\text {LUMO }}$ is indicative of the higher affinity of the inhibitor to accept electrons under some chemical interaction conditions. The energy gap $\left(\Delta \mathrm{E}=\mathrm{E}_{\mathrm{LUMO}}-\mathrm{E}_{\mathrm{HOMO}}\right)$, the lesser $\Delta \mathrm{E}$, the easier the electron transfer from HOMO to LUMO and the higher adsorption ability of the expired nizatidine drug on brass, hence the IE will be greater. All outcome data in Table 11 displayed that the expired nizatidine drug has the lowest total energy which means that the adsorption of the expired nizatidine drug is higher Fig. (15) provides the electron density maps of $\mathrm{HOMO}$ and LUMO for the tested expired nizatidine drug. 


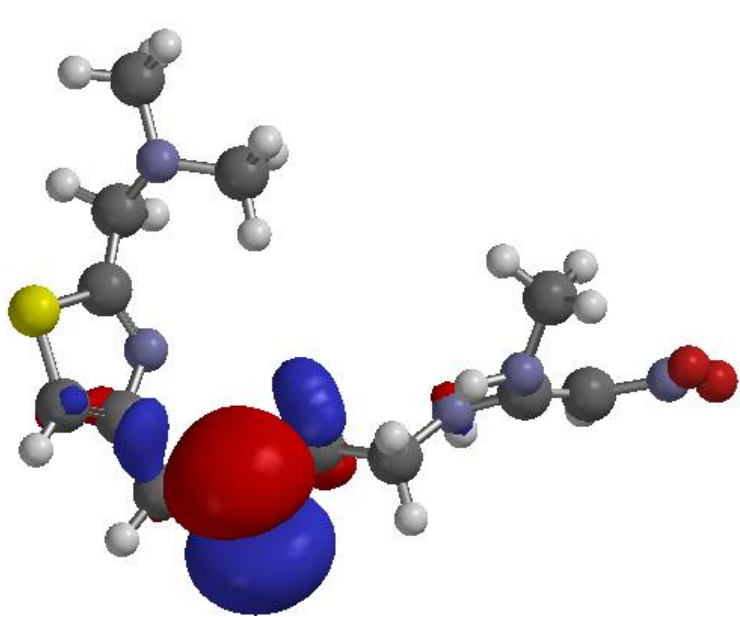

HOMO

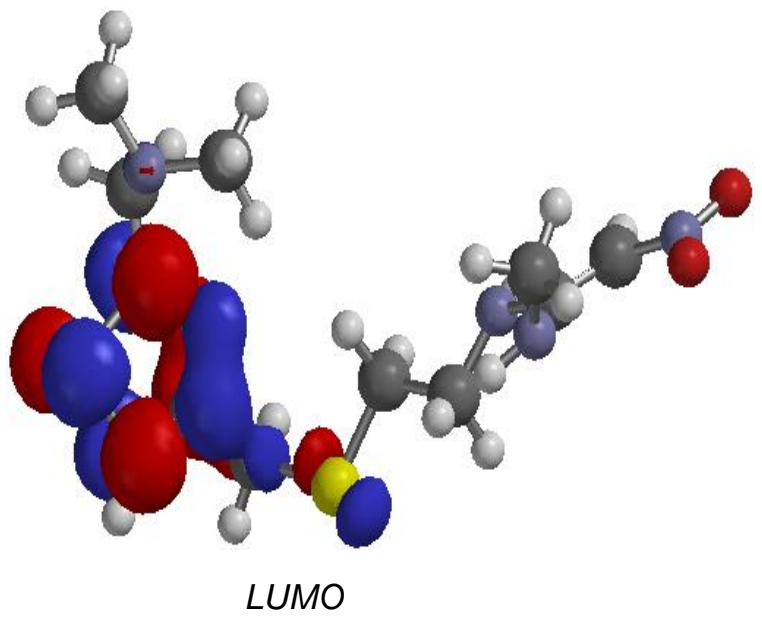

LUMO

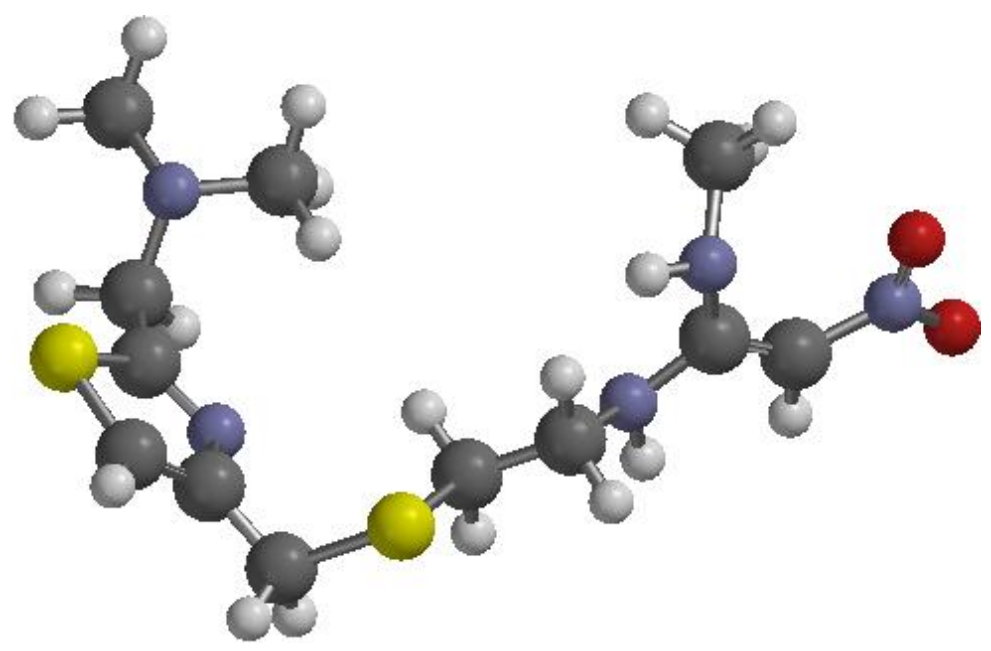

Molecular orbital

Figure 15- (HOMO) and (LUMO) of molecular orbit

\section{Slika 15. HOMO i LUMO molekularne orbitale}

Table 11. Data obtain from quantum chemical properties for expired nizatidine drug.

Tabela 11. Podaci dobijeni iz kvantnih hemijskih svojstava za istekli lek nizatidin.

\begin{tabular}{|l|c|}
\hline$E_{\text {Hомо, }}(\mathrm{ev})$ & -9.40 \\
\hline$E_{\text {LUMO }}(\mathrm{ev})$ & -0.99 \\
\hline$\Delta \mathrm{E}_{\mathrm{N}}\left(\mathrm{E}_{\mathrm{L}}-\mathrm{E}_{\mathrm{H}}\right)$ & 8.41 \\
\hline$\mu,($ Dipole moment) & 8.530 \\
\hline
\end{tabular}

\section{INHIBITION MECHANISM}

Considering the result data of the tests in our study, we explore the mechanism of dissolution protection of a-brass in $1 \mathrm{M} \mathrm{HCl}$ by expired nizatidine drug. The interactive drug molecules displaced the water molecules located at brass/solution interface. In general, it is possible that the adsorption of drug at the brass / solution interface is the first step in the mechanism of action of drug in destructive environments. The adsorption of the drug molecules at the brass / solution interface may due to: "i) Electrostatic attraction among inhibitor and brass molecules ii) Interaction of unshared pairs of electrons in the expired nizatidine drug with the brass iii) Interaction of electrons iii) Interaction of electrons $\pi$ with brass" vi) A summation of the preceding. The expired nizatidine drug action mechanism for $\alpha$-brass in $1 \mathrm{HCl}$ was discussed in terms of physical adsorption on the $\alpha$-brass interface. This proved from the effect of temperature (\%IE decreases by raising temperature). The $\alpha$-brass surface with its positive 
charge prefers the adsorption of $\mathrm{Cl}^{-}$to produce a negative charge surface. This molecule (nizatidine) will present in the protonated form, so it can adsorb directly on the negative surface of $\alpha$-brass [53] in acidic medium by electrostatic attraction as shown below.

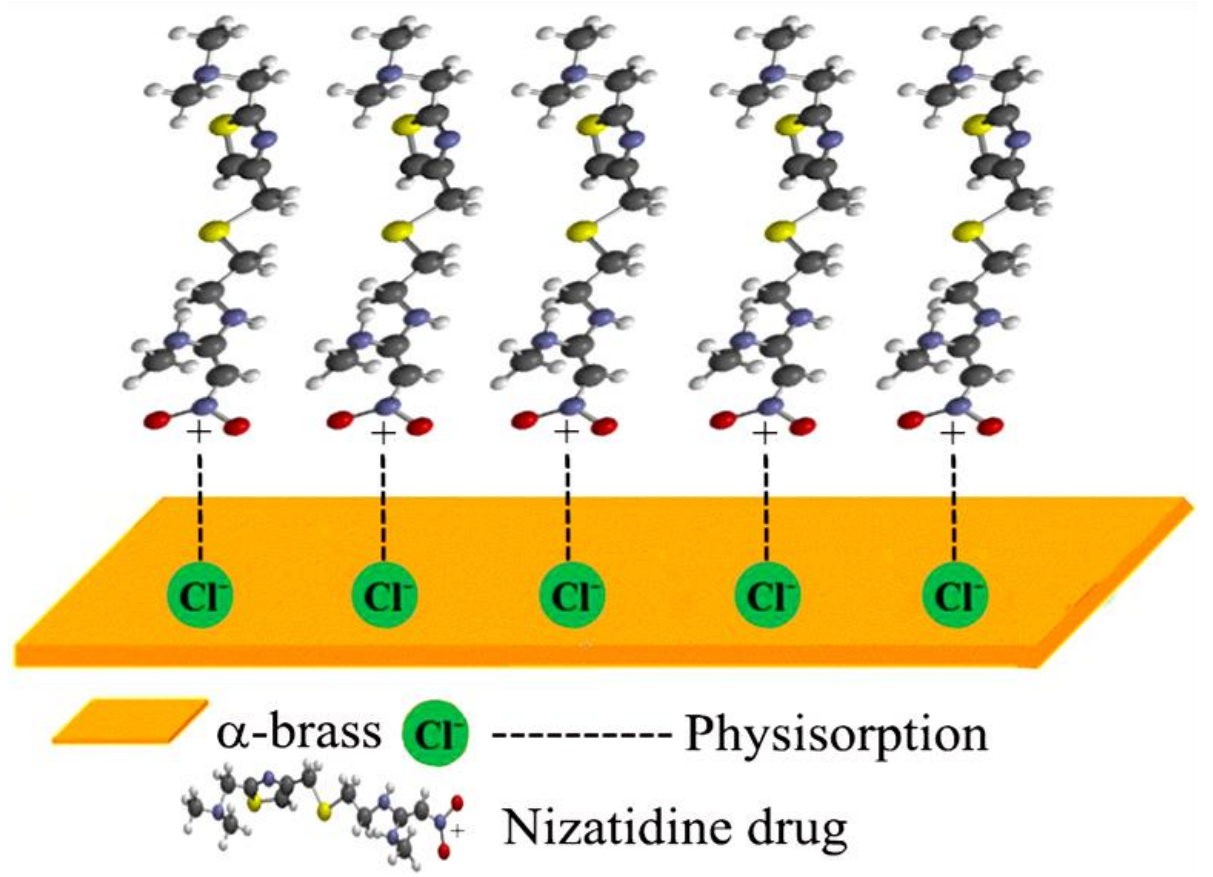

Table 12 shows a comparison \%IE with presence of different drugs. The present nizatidine gives significantly important corrosion \% IE compared to other drugs. Thus, the present nizatidine drug can utilized as corrosion inhibitor with promising results.

Table 12. Performance comparison of some expired drugs as corrosion inhibitors

Tabela 12. Poređenje performansi nekih lekova sa istekom roka trajanja kao inhibitora korozije

\begin{tabular}{|c|c|c|c|}
\hline Inhibitor (drug) & sample & $\% \mathrm{IE}$ & References \\
\hline Penciillin G & mild steel & 73.7 & 54 \\
\hline Domperidone & $\mathrm{Al}$ & 89.1 & 55 \\
\hline Cloxacillin & mild steel & 81.0 & 56 \\
\hline Pantoprazole & $\mathrm{Al}$ & 59.0 & 57 \\
\hline Quinoline & mild steel & 88.7 & 58 \\
\hline Nizatidine & $\alpha$-brass & 95.0 & present work \\
\hline
\end{tabular}

\section{CONCLUSIONS}

The investigated expired nizatidine drug were investigated under conditions in $1 \mathrm{M} \mathrm{HCl}$. From the obtained data of the study, the percentage IE from chemical and electrochemical tests were best agreement and the potential of nizatidine drug improves with lowering temperature and raising the doses of expired nizatidine in aggressive environment. PP tests exposed that nizatidine drug function as mixed kind. The obtained data from EIS test runs parallel with PP tests. The adsorption procedure conforms Langmuir isotherm. FTIR, EDX and AFM analyses also prove the formation of protective film on the surface of brass interface in $1 \mathrm{M} \mathrm{HCl}$.

\section{REFERENCES}

[1] R.F.North, M.J.Pryar (1970) The influence of corrosion product structure on the corrosion rate of Cu-Ni alloys, Corros. Sci., 10, 297-311.

[2] G.Quartarone, G.Moretti, T.Bellami (1998) Using Indole to Inhibit Copper Corrosion in Aerated $0.5 \mathrm{M}$ Sulfuric Acid, Corrosion, 54, 606-618.

[3] W.Ozgowicz, E.O.Kalinowska, B.Grzegorczyk (2010) Comparing of optical properties and morphology of polyoxadiazoles with $\mathrm{CF}_{3}$ groups, Journal of Achievements in Materials and Manufacturing Engineering, 40, 1-13.

[4] D.Tianbao, C.Jiajian, C.Dianzhen (2001) N, NDipropynoxy methyl amine trimethyl phosphonate as corrosion inhibitor for iron in sulfuric acid, $\mathrm{J}$. Mater. Sci., 36, 3903-3907.

[5] P.Morales-Gil, G.Negron-Silva, M.Romero-Romo, C.Angeles-Chavez, M.Palomar-Pardave (2004) Corrosion inhibition of pipeline steel grade API $5 \mathrm{~L}$ X52 immersed in a $1 \mathrm{M} \mathrm{H}_{2} \mathrm{SO}_{4}$ aqueous solution using heterocyclic organic molecules, Electrochim.Acta., 49, 4733-4741. 
[6] J.M.Bastidas, J.L.Polo, E.Cano (2000) Substitutional inhibition mechanism of mild steel hydrochloric acid corrosion by hexylamine and dodecylamine, J.Appl. Electrochem., 30, 11731177.

[7] B.Zerga, A.Attiyibat, M.Sfaira, M.Taleb, B. Hammouti, M.Ebn Touhami, S.Radi, Z.Rais (2010) Effect of some tripodal bipyrazolic compounds on C38 steel corrosion in hydrochloric acid solution, J. Appl. Electrochem., 40, 1575-1582.

[8] S. Tamil Selvi, V.Raman, N.Rajendran (2003) Corrosion inhibition of mild steel by benzotriazole derivatives in acidic medium, J. Appl. Electrochem. 33, 1175-1182.

[9] A.S.Fouda, S.M.Rashwan, M.Abdelfatah (2019) Corrosion Inhibition of stainless steel 304 in hydrochloric acid solution using clindamycin antibiotic as Eco-friendly inhibitor, Zastita Materijala, 60(1), 3-18.

[10] D.Lowmunkhong, P.Ungthararak, J.Sutthivaiyakit (2009) Tryptamine as a corrosion inhibitor of mild steel in hydrochloric acid solution, Corros. Sci., 52, 30-36.

[11] M.Zerfaoui, H.Oudda, B.Hammouti, M.Benkaddour (2004) Inhibition of corrosion of iron in citric acid media by amino acids, Prog. Org. Coat., 51, 134138.

[12] A.Chetaouani, B.Hammouti, A.Aouniti, N.Benchat, T.Benhadda (2002) New synthesized pyridazine derivatives as effective inhibitors for the corrosion of pure iron in $\mathrm{HCl}$ medium, Prog. Org. Coat., 45, 373378.

[13] K. A.Mohamed (2004) Semiempirical investigation of the inhibition efficiency of thiourea derivatives as corrosion inhibitors, J. Electroanal. Chem., 567, 219-225.

[14] D.K.Yadav, B.Maiti, M.A.Quraishi (2010) Electrochemical and quantum chemical studies of 3,4-dihydropyrimidin-2(1H)-ones as corrosion inhibitors for mild steel in hydrochloric acid solution, Corros. Sci., 52, 3586-3598.

[15] A.S.Fouda, F.I.El-Dossoki, E.A.Sello (2019) Esomeprazole Magnesium Trihydrate drug as a potential non-toxic corrosion inhibitor for mild steel in acidic media, Zastita Materijala, 60(3), 245-259.

[16] K.S. Jacob, G. Parameswaran (2009) Corrosion inhibition of mild steel in hydrochloric acid solution by Schiff base furoin thiosemicarbazone, Corros. Sci., 52, 224-228.

[17] A.Ostovari, S.M.Hoseinieh, S.Shadizadeh, S. Hashemi (2009) Corrosion inhibition of mild steel in $1 \mathrm{M} \mathrm{HCl}$ solution by henna extract: A comparative study of the inhibition by henna and its constituents (Lawsone, Gallic acid, a-D-Glucose and Tannic acid), Corros. Sci., 51, 1935-1949.

[18] F.C.Giacomelli, C.Giacomelli, M.F.Amadori, V.Schmidt, A.Spinelli (2004) Inhibitor effect of succinic acid on the corrosion resistance of mild steel: electrochemical, gravimetric and optical microscopic studies, Mater. Chem. Phys., 83,124128.
[19] A.K.Satapathy, G.Gunasekaran, S.C.Sahoo, K. Amit, P.V.Rodrigues (2009) Corrosion inhibition by Justicia gendarussa plant extract in hydrochloric acid solution, Corros. Sci., 51, 2848-2856.

[20] X.H.Li, S.D.Deng, H.Fu (2010) Inhibition by Jasminum nudiflorum Lindl. leaves extract of the corrosion of cold rolled steel in hydrochloric acid solution, J. Appl. Electrochem., 40, 1641-1649.

[21] P.Lima-Neto, A.P. Araujo, W.S.Araujo, A.N. Correia (2008) Study of the anticorrosive behavior of epoxy binders containing non-toxic inorganic corrosion inhibitor pigments, Prog. Org. Coat., 62,344-350.

[22] R.S.Abd El Hameed, H.I.Al Shafey, S.A.Soliman, M.S.Metwally (2008) Pyrazole Derivatives as Corrosion Inhibitor for C- Steel in Hydrochloric, Acid Medium, Al Azhar Bull. Sci., 19, 283-305.

[23] Xie, G.M., Ma, Z.Y. and Geng, L. (2008) Effects of Friction Stir Welding Parameters on Mechanical and Microstructure Properties of Brass Joint. Japan Institute of Metals. Material Transactions, 49, 16981701.

[24] R. S.Abd El Hameed, H.I.Al Shafey, E.A.Ismail (2009) studies on corrosion inhibition of c-steel in $1 \mathrm{~m}$ acetic acid solutions by ethoxylated poly (ethylene terphthalate) derived from plastic waste, Al Azhar Bull. Sci., 20, 185-197.

[25] A.M.Atta, M.A.El-Sockary, S.Abdel Salam (2007) Recycled Poly(ethylene terephthalate) Waste Oligomers as Corrosion Inhibitors of Steel, Progress in Rubber, Plastics and Recycling Technology, 23, 241-257.

[26] I.B.Obot, N.O.Obi-Egbedi, S.A.Umoren (2009) Antifungal drugs as corrosion inhibitors for aluminum in $0.1 \mathrm{M} \mathrm{HCl}$, Corros. Sci., 51,1868-1875.

[27] M.Abdallah (2004) Antibacterial Drugs as Corrosion Inhibitors for Corrosion of Aluminum in Hydrochloric Acid Solution, Corros. Sci., 46, 1981-1996.

[28] A.S.Fouda, A. A.Al-Sarawy, F.S.Ahmed, H.M.ElAbbasy (2009) Corrosion inhibition of aluminum 6063 using some pharmaceutical compounds, Corros. Sci., 51,485-492.

[29] I.B.Obot, N.O.Obi-Egbedi (2010) Inhibition of Aluminum Corrosion in Hydrochloric Acid Using Nizoral and the Effect of lodide Ion Addition, E-J. Chem., 7, 837-843.

[30] R.S.A.Hameed (2009) Expired Ranitidine drugs as corrosion inhibitor for aluminum $1 \mathrm{M}$ Hydrochloric acid, Al Azhar Bull. Sci., 20, 151-163.

[31] E.E.Oguzie (2005) Corrosion inhibition of mild steel in hydrochloric acid solution by methylene blue dye, Mater. Letters, 59, 1076-1079.

[32] K.F.Khaled (2008) Application of electrochemical frequency modulation for monitoring corrosion and corrosion inhibition of iron by some indole derivatives in molar hydrochloric acid, Mater. Chem. Phys., 112, 290-300.

[33] K.F.Khaled (2009) Evaluation of electrochemical frequency modulation as a new technique for monitoring corrosion and corrosion inhibition of carbon steel in perchloric acid using hydrazine carbodithioic acid derivatives, J. Appl. Electrochem., 39, 429-438. 
[34] R.W.Bosch, J.Hubrecht, W.F.Bogaerts, B.C.Syrett (2001) Electrochemical Frequency Modulation: A New Electrochemical Technique for Online Corrosion Monitoring, Corrosion, 57, 60-70.

[35] A.S.Fouda, K.Shalabi, A.El-Hossiany (2016) Moxifloxacin Antibiotic as Green Corrosion Inhibitor for Carbon Steel in $1 \mathrm{M} \mathrm{HCl}$, J Bio Tribo Corros, 2,18-25.

[36] E.Cano, J.L.Polo, A.L.Iglesia (2004) A Study on the Adsorption of Benzotriazole on Copper in Hydrochloric Acid Using the Inflection Point of the Isotherm, Adsorption, 10, 219-225.

[37] A.S.Fouda, A.El-Hossiany, H.Ramadan (2017) Calotropis procera plant extract as green corrosion inhibitor for 304 stainless steel in hydrochloric acid solution, Zastita Materijala, 58(4), 541-555.

[38] Y.A.Bereket, A.Kivrak, A.Balaban, B. Erk (2005) Effect of Schiff Bases Containing Pyridyl Group as Corrosion Inhibitors for Low Carbon Steel in $0.1 \mathrm{M}$ $\mathrm{HCl}$, J Appl Electrochem, 35, 1025-1032.

[39] F.Bentiss, M.Traisnel, M.Lagrenee (2000) The substituted 1,3,4-oxadiazoles: a new class of corrosion inhibitors of mild steel in acidic media, Corros Sci., 42, 127-146.

[40] A.S.Fouda, H.lbrahim, S.Rashawn, A.El-Hossiany, R.M.Ahmed (2018) Expired Drug (pantoprazole sodium) as a Corrosion Inhibitor for High Carbon Steel in Hydrochloric Acid Solution, Int. J. Electrochem. Sci., 13, 6327-6346.

[41] A.S.Fouda, M.Eissa, A.El-Hossiany (2018) Ciprofloxacin as Eco-Friendly Corrosion Inhibitor for Carbon Steel in Hydrochloric Acid Solution, Int. J. Electrochem. Sci., 13, 11096-11112.

[42] M.El Achouri, S.Kertit, H.M.Gouttaya, B.Nciri, Y. Bensouda, L.Perez, M.R.Infante, K.Elkacemi (2001) Corrosion inhibition of iron in $1 \mathrm{M} \mathrm{HCl}$ by some gemini surfactants in the series of alkanediyl- $\alpha, \omega$ bis-(dimethyl tetradecyl ammonium bromide), Prog. Org. Coat., 43, 267-273.

[43] A.S.Fouda, F.M.El-Taweel, N.H.Mohamed (2019) Evaluation of the Inhibition Effect of Some Novel Organic Compounds (phenol derivatives) for Corrosion of $\alpha$-brass in Acid Solutions, Int. J. Electrochem. Sci., 14, 188-207.

[44] R.Macdonald (1987) Impedance spectroscopy and its use in analyzing the steady-state $A C$ response of solid and liquid electrolytes, J. Electroanal. Chem., 223, 25-50.

[45] S.F.Mertens, C.Xhoffer, B.C.Decooman, E. Temmerman (1997) Short-Term Deterioration of Polymer-Coated $55 \%$ Al-Zn - Part 1: Behavior of Thin Polymer Films, Corrosion, 53, 381-388.

[46] A.S.Fouda, S.A.Abd El-Maksoud, A.El-Hossiany, A. Ibrahim (2019) Corrosion Protection of Stainless Steel 201 in Acidic Media using Novel Hydrazine Derivatives as Corrosion Inhibitors, Int. J. Electrochem. Sci., 14, 2187-2207.
[47] A.S.Fouda, M.Abdel Azeem, S.A.Mohamed, A.ElHossiany, E. El-Desouky (2019) Corrosion Inhibition and Adsorption Behavior of Nerium Oleander Extract on Carbon Steel in Hydrochloric Acid Solution, Int. J. Electrochem. Sci., 14, 3932 3948.

[48] F.M.Reis, H.G.De Melo, I.Costa (2006) EIS investigation on Al 5052 alloy surface preparation for self-assembling monolayer, Electrochim. Acta., $51,1780-1788$.

[49] M.Lagrenee, B.Mernari, M.Bouanis, M.Traisnel, F. Bentiss (2002) Study of the mechanism and inhibiting efficiency of 3,5-bis(4-methylthiophenyl)$4 \mathrm{H}-1,2,4$-triazole on mild steel corrosion in acidic media, Corros. Sci., 44, 573-588.

[50] A.S.Fouda, S.A.Abd El-Maksoud, A. El-Hossiany, A. Ibrahim (2019) Evolution of the Corrosion-inhibiting Efficiency of Novel Hydrazine Derivatives against Corrosion of Stainless Steel 201 in Acidic Medium, Int. J. Electrochem. Sci., 14, 6045-6064.

[51] H.Ma, S.Chen, L.Niu, S.Zhao, S.Li, D.Li (2002) Inhibition of copper corrosion by several Schiff bases in aerated halide solutions, J. Appl. Electrochem., 32, 65-72,

[52] E.Kus, F.Mansfeld (2006) An evaluation of the electrochemical frequency modulation (EFM) technique, Corros. Sci., 48, 965.-979,

[53] A.S.Fouda, M.A.Abd El-Ghaffar, M.H.Sherif, A. Taher El-Habab, A.El-Hossiany (2020) Novel Anionic 4-Tert-Octyl Phenol Ethoxylate Phosphate Surfactant as Corrosion Inhibitor for C-steel in Acidic Media, Protection of Metals and Physical Chemistry of Surfaces, 56 (1), 189-200.

[54] Yi Liang, Ch.Wang, J.Sheng, L.Jun Wang, J.Jun Fu (2015) The Penicillin Derivatives as Corrosion Inhibitors for Mild Steel in Hydrochloric Acid Solution: Experimental and Theoretical Studies Int. J. Electrochem. Sci., 10, 8072 - 8086.

[55] S. K.Rajappa, T.V.Venkatesh (2016) Investigation of Corrosion Protection of Aluminum by Domperidone in Hydrochloric Acid Medium, International Journal of Innovative Research in Science, Engineering and Technology, 5(3), 39173925.

[56] S.H.Kumar, S.Karthikeyan (2012) Inhibition of mild steel corrosion in hydrochloric acid solution by cloxacillin drug, J. Mater. Environ. Sci., 3(5), 925934.

[57] H.Lgaz, M.Saadouni, R.Salghi, S.Jodeh, M.Elfaydy, B.Lakhrissi, S.Boukhris, H.Oudda (2016) Investigation of Quinoline Derivatives as Corrosion Inhibitors for Mild Steel in $\mathrm{HCl} 1.0 \mathrm{M}$, Der Pharmacia Lettre, 8 (18),158-166.

[58] D.H.Kraus, S.J.Rehm, S.E.Kinney (1988) The evolving treatment of necrotizing external otitis, The Laryngoscope, 98(9), 934-939. 


\section{IZVOD}

\section{NIZATIDIN LEK KAO EKOLOŠKI INHIBITOR KOROZIJE ZA LEGURE $\alpha$-MESINGA U VODENIM RASTVORIMA}

Istekli lek nizatidine (END) proučavan je kao inhibitor a-mesinga u $1 \mathrm{M} \mathrm{HCl}$ korišćenjem gubitka težine (WL) i elektrohemijskim metodama, naime, AC impedancijom (EIS), potenciodinamičkom polarizacijom (PP) i testovima elektrohemijske frekventne modulacije (EFM). Efikasnost zaštite (\% IE) poboljšana je povećanjem doze isteklog leka nizatidina $i$ smanjuje se $s$ povećanjem temperature. Efikasnost zaštite (\% IE) dostiže maksimalnu vrednost $95 \%$ pri većoj dozi istrošenog leka nizatidina na $25^{\circ} \mathrm{C}$. Podaci PP pokazali su da se lek nizatidin ponaša kao lek mešovite vrste. Zaštita od korozije a -mesinga od strane leka nizatidina može da se uklapa u adsorpcionu sposobnost molekula leka nizatidina na reaktivna mesta $\alpha$-mesingove površine. Adsorpcija leka sledi Langmuirovu izotermu adsorpcije. Ispitivana je površinska morfologija $\alpha$-mesinga. Rezultati dobijeni različitim metodama se odlično slažu.

KIjučne reči: Inhibicija kiseline, a-mesing, Nizatidin, EFM, EIS, AFM, FTIR.

Naučni rad

Rad primljen: 30. 04. 2020.

Rad korigovan: 14. 07. 2020.

Rad prihvaćen: 22. 07. 2020.

(C) 2020 Authors. Published by Engineering Society for Corrosion. This article is an open access article distributed under the terms and conditions of the Creative Commons Attribution 4.0 International license (https://creativecommons.org/licenses/by/4.0/) 